\title{
La polémica sobre el judeoespañol en la prensa sefardí del Imperio otomano: más materiales para su estudio*
}

\author{
Elena Romero ** \\ ILC, CCHS - CSIC, Madrid
}

En el presente artículo se publican y estudian doce textos aljamiados tomados de la prensa sefardí que ilustran sobre la polémica acerca de la supervivencia del judeoespañol, entablada entre los sefardíes del Imperio otomano desde finales del siglo XIX en adelante. Los textos proceden de los periódicos El Tiempo de Constantinopla, La Época y El Avenir de Salónica y El Meseret de Esmirna, y vieron la luz en los años 1883, 1893, 1900, 1904 y 1906. Los temas a tratar se distribuyen en los siguientes apartados: 1) Los españoles ante el judeoespañol y el problema de los caracteres rašíes; 2) El rechazo de los sefardíes a España y a su herencia lingüística versus la campaña de Ángel Pulido; y 3) El turco como solución. Para ilustrar tales temas se aduce algún otro texto de fuente española, así como la versión aljamiada de un conocido artículo de Leon Lamouche, el cual sirve de un a modo de resumen de todo lo expuesto.

Palabras Clave: Lengua judeoespañola; prensa sefardí; Ángel Pulido; España y los judíos sefardíes; la polémica sobre el judeoespañol; edición de textos; glosario.

The Controversy Concerning Judeo-Spanish in the Ottoman Sephardic Newspapers: More Materials For StUdy.- The article studies twelve newspaper Sephardic texts illustrating the controversy concerning the survival of Judeo-Spanish among the Sephardic Jews of the Ottoman Empire from the end of the $19^{\text {th }}$ century on. The texts were published in 1883, 1893, 1904 and 1906 in the newspapers El Tiempo (Constantinople), La Epoca and El Avenir (Salonika), and El Meseret (Esmirna). The issues covered are the following: 1) Spaniards facing Judeo-Spanish and the problem of Rashi script; 2) The rejection by the Sephardic Jews of Spain and the Spanish linguistic heritage, and the opposition to Angel Pulido's campaign; and 3) The adoption of the Turkish language as a solution. Other texts of Spanish origin are cited to illustrate these issues, as well as the aljamiado version of the well known article by Leon Lamouche, that serves to summarize the arguments presented.

Keywords: Judeo-Spanish; Sephardic Newspapers; Angel Pulido; Spain and the Sephardic Jews; The Polemic on Judeo-Spanish; Edition of Texts; Glossary.

* El presente artículo se ha elaborado con materiales acopiados durante el Proyecto de Investigación «Sefarad siglo XXI (2005-2007): Edición y estudio filológico de textos sefardíes» (MEC, DGS, HUM2005-01747/FILO). Agradezco su atenta lectura del original a Dora Mancheva, cuyas sugerencias he seguido en un buen número de casos.

** elena.romero@cchs.csic.es 
En un congreso celebrado recientemente en Madrid me he ocupado de la polémica suscitada en la prensa judeoespañola en torno al mantenimiento y pervivencia del judeoespañol, polémica que se plasmó en cientos de artículos desde más o menos la última década del siglo XIX hasta unos años antes de la Segunda guerra mundial, y que, como allí decía, por sus considerables repercusiones posteriores considero de especial interés para los estudiosos de la lengua y de la literatura sefardíes.

Para centrar algunos conceptos básicos, permítaseme repetir a grandes rasgos algunas de las cosas dichas en mi aludida comunicación. La polémica nos muestra cómo hacia el último tercio del siglo XIX los intelectuales sefardíes empezaron a mostrar un total desprecio por la lengua que había sido suya durante siglos y que tan buenos frutos les había dado como vehículo de comunicación y de creación literaria. Su antagonismo e incluso aborrecimiento hacia el judeoespañol parece tener su origen en las nuevas realidades culturales fruto de la modernidad que sacudió las mentes de los sefardíes por aquellas calendas.

En esencia, los mimbres de la polémica ya son de todos conocidos ${ }^{1}$ y también cuáles fueron los dos grupos de polemistas enfrentados.

${ }^{1}$ Por no dejar cabos sueltos, repito aquí la sucinta bibliografía sobre el tema que anoto en mi citada comunicación (notas 2-3). Se ha ocupado magistralmente de la cuestión David BunIS en su «Modernization and the Language Question among Judezmo-Speaking Sephardim of the Ottoman Empire», en H. E. GoldBerg (ed.), Sephardi and Middle Eastern Jewries: History and Culture in the Modern Era (Bloomington 1996) págs. 226-239. Vid. también los artículos de Amor Ayala, «"Por nu'estra lingu'a” (Sofía. 1924): un artículo periodístico sobre la lengua y la identidad entre los sefardíes en la Bulgaria de Entreguerras», Judenspanisch X (Neue Romania 35) (2006) págs. 83-107; Amor Ayala \& Winfried Busse, «"Por nu'estra lingu'a”. Edición del texto publicado en El Manadero (Sofía 1924)», Judenspanisch X (Neue Romania 35) (2006) págs. 99-107; Eyal GINIO, «"Learning the beautiful language of Homer:" Judeo-Spanish speaking Jews and the Greek language and culture between the Wars», Jewish History 16/3 (2002) págs. 235-262; Christine H. LOCHOW-DrÜKE, «La campaña a favor de la propagación del idioma turco entre los sefardíes», en Pablo Martín Asuero y Karen Gerson ŞARHon, Ayer y hoy de la prensa judeoespañola (Estambul 2007) págs. 61-70; Aldina QuinTANA, «Proceso de recastellanización del judesmo», en Judit Targarona Borrás y Ángel SáEnz Badillos (eds.), Jewish Studies at the Turn of Twentieth Century (Leiden et al. 1999) vol. II, págs. 593-602; Albert de VIDAS, «The Language Controversy among the Sephardim of the Ottoman Empire at the Turn of the Century», en David F. Altabé et al. (eds.), Studies on Turkish History: Political and Social Relations, Literature and Linguistics, The Quincentennial Papers (New York 1996) págs. 147-161; etc. Hace tiempo yo misma dediqué atención al tema en mi libro La creación literaria en lengua sefardí (Madrid 1992) págs. 193-198, refiriéndome a algunas de las personas que entraron en liza, dejando constancia de un buen número de artículos periodísticos en los que se plasmó la polémica y publicando un par de textos al respecto aparecidos en 1925 en El Pueblo de Salónica. Sobre el desprecio de los sefardíes por su lengua y la actitud desdeñosa hacia el judeoespañol de los eruditos españoles, tema del que me ocupo luego, puede verse, por ejemplo, Iacob M. Hassán, «El español sefardí (judeoespañol, ladino)», en Manuel Seco y Gregorio SALVAdor (coords.), La lengua española hoy (Madrid 1995) págs. 117-140 y «La lengua y la literatura sefardíes en el marco del hispanismo», Raíces 52-53 (2002) págs. 20-30; Winfried Busse, «Le judéo-espagnol - un jargon?», en Winfried Busse - Marie-Christine VArol-Bornes (dirs.), Hommage à Haïm Vidal Sephiha (Berne et al. 
Un grupo aparece encabezado por los jóvenes intelectuales ilustrados, recién salidos de las escuelas francesas de la Alianza Israelita Universal y de otras escuelas -italianas y alemanas- europeas que encontraban el judeoespañol de sus padres y abuelos pobre para la creación literaria e ineficaz para reflejar los aportes culturales y científicos del mundo moderno, y que propugnan el abandono del judeoespañol para entregarse a otras lenguas.

Frente a ellos se alzan los defensores del judeoespañol, muchos de los cuales propugnan diferentes sistemas para actualizarlo: abandonar los caracteres hebreos con los que tradicionalmente se ha escrito el judeoespañol y que consideran como un gueto cultural, purificar el judeoespañol acercándolo al español, e incluso buscando la idoneidad de la expresividad literaria en el habla, no ya de los cultos, sino de la gente de a pie. Obvio es decir que a lo largo de los años la polémica se desarrolla en judeoespañol que es la lengua común que todos conocen.

Lo que pretendo en este artículo es aportar una serie de textos inéditos que avalan o complementan lo que otros investigadores han dicho sobre tal polémica. Para ello me valgo de doce textos aljamiados -no computo aquí los procedentes de otras fuentes- publicados, en los años 1883, 1893, 1900, 1904 y 1906, mayoritariamente en El Tiempo de Constantinopla y en La Época de Salónica, y un par de ellos en El Avenir de Salónica y en El Meseret de Esmirna. Los distribuyo por su tema mayoritario -si bien en algunos de ellos aparecen varios asuntos a la vez- y no por su cronología.

\section{LOS ESPAÑOLES ANTE EL JUDEOESPAÑOL; EL PROBLEMA DE LOS CARACTERES RAŠÍES}

A tal actitud despreciativa sobre el judeoespañol por parte de los más cultos de sus hablantes es cierto que contribuyó el ya citado proceso de europeización y mayormente de afrancesamiento de los intelectuales sefardíes. Pero podemos ir más allá y afirmar que, si bien no fue factor desencadenante, desde luego no contribuyeron a mejorar la situación las posturas desdeñosas que mostraron no pocos intelectuales españoles cuando por aquellos finales del siglo XIX y principios del XX se producen los primeros de una larga serie de «descubrimientos» casuales del fenómeno lingüístico sefardí, por mucho que se dijeran interesados

1996) págs. 239-245; Albert DE VIDAS, «The Sephardim and Spain at the Turn of the Century», en ibíd. págs. 545-563 (vid. también su artículo mencionado supra); y Henri NAHUM, «Un journal judéo-espagnol à Smyrne avant la Première Guerre Mondiale: La Boz del Pueblo», ibíd. págs. 565-580. 
por esa lengua heredera de la hispánica de cuya existencia acababan de enterarse. Aquella actitud ciertamente soberbia de escritores, filólogos y políticos españoles de la época no sirvió en modo alguno para dar al judeoespañol el cierto espaldarazo que precisaba en unos momentos en que se estaba poniendo en tela de juicio su propia existencia ${ }^{2}$.

Ya me he ocupado de la cuestión en otro lugar ${ }^{3}$; pero quiero recordar aquí las palabras que recoge Ángel Pulido ${ }^{4}$, puestas en boca de quien dice ser «distinguido catedrático, honra del profesorado actual» y que por mencionar a continuación su interés «acerca de los romances judíos, filología antigua, sedimentos fonéticos del idioma castellano» quizá podamos pensar en un nombre que no me atrevo a pronunciar en voz alta. Dice quien fuera el eximio catedrático las siguientes palabras que no tienen desperdicio:

Porque, ¿para qué hacer nada? -¿Idioma? Ya no hay sino una ruina lamentable que vale más se pierda por bien de ellos y de nosotros.- ¿Raza sefardí? Es de las israelitas la más atrasada y miserable [...] siempre en la barbarie de Turquía y Marruecos, ¡cómo ha de estar! [...] ¿Ayudarles, instruirles? Serán tiempo y dinero malgastados [...] Es ya una batalla perdida; Francia, Alemania, Italia... nos han derrotado [...] Hace cuarenta años tal vez hubiéramos conseguido algo, antes de la obra de la Alliance; pero ¡hoy ya!.- ¿Repatriarlos? Sería un peligro, porque levantarían en España un antisemitismo que ahora no existe...

Otro ejemplo paradigmático de lo mismo aparece en un artículo que se publicó en el periódico de Salónica La Época (4 iyar 5643 / 11 mayo 1883, págs. 237 239) bajo el título de «España en Oriente: Los jidiós españoles»; así comienza:

Debajo de este título un jornal español, El Día ${ }^{5}$, que aparece en Madrid, publica el artículo siguiente.

2 Vid. la bibliografía sobre el tema que recojo en nota anterior; a ella puede añadirse mi artículo «Historia y literatura», en Elena Romero (ed.), Iacob M. HASSÁn y Ricardo IzQuierdo Benito (coords.), Sefardíes: Literatura y Lengua de una Nación Dispersa (Cuenca 2008) págs. 155-192: págs. 180-182.

3 En mi libro El teatro de los sefardíes orientales (Madrid 1979) pág. 410 me refería a la callada por respuesta que el senador Ángel Pulido le daba al historiador y autor sefardí Abraham Galante, quien le sondeaba sobre la posibilidad de publicar en España alguna de sus obras. Vid. Ángel Pulido, Españoles sin patria y la raza sefardí (Madrid 1905) pág. 476.

${ }^{4}$ En Españoles pág. 525.

${ }^{5}$ Sobre este periódico vid. Pedro Gómez Aparicio en su Historia del periodismo español: De la Revolución de Septiembre al desastre colonial (Madrid 1971) págs. 418-421, de donde tomo los datos que siguen. 
El aludido periódico madrileño lo fundó el 21 de abril de 1880 Camilo Hurtado de Amézaga, Marqués de Riscal; pervivió durante cuarenta y dos años, siendo su director el propio Marqués hasta 1886.

Pero antes de seguir adelante conviene destacar un hecho curioso. Al ocuparse del periódico El Luzero de la Pasensia, Paloma Díaz-Mas y Amelia Barquín nos dicen ${ }^{6}$ que en los números 15 y 16 del año 1886, primero de dicho periódico, se publica en dos entregas el artículo «Judíos Españoles en Oriente», que había aparecido en la Revista de Geografía Comercial publicada bimensualmente en Madrid entre 1885 y 1896. En la citada revista española el artículo que comentamos va precedido de la siguiente entradilla donde se precisa su origen. Dice así: «[...] vamos a reproducir unos artículos que publicó sin firma hace algún tiempo El Día [...]».

Lo publicado en La Época y lo que apareció en El Luzero 1:15 (3 tamuź 5646 / [J] 24 Junie 1886 [= G: 6 julio 1886 ${ }^{7}$ ]) págs. 237-240 y 1:16 (17 tamuź 5646 / [J] 8 Julie 1886 [= G: 20 julio 1886]) págs. 250-253 es prácticamente lo mismo con las siguientes variaciones más significativas: el título -en La Época «España en Oriente: Los jidiós españoles» y en El Luzero «Judíos Españoles en Oriente»-; la extensión -más breve el texto de La Época, que sólo reproduce el apartado núm. I de los dos que tiene el artículo original-; y sobre todo y muy especialmente que el publicado en La Época está adaptado al judeoespañol y escrito en aljamiado, mientras que el de El Luzero reproduce en caracteres latinos el texto de la revista española.

Así pues y ateniéndonos a los datos cronológicos, parece ser que el artículo publicado en El Día en una fecha que no se nos precisa, pero posterior a la de su fundación en 1880, y reproducido en la Revista de Geografía Comercial no antes de 1885, fecha de su inicio, llegó directamente de El Día a la redacción de La Época en mayo de 1883, fecha de su publicación, y por vía indirecta y con un retraso de al menos tres años a El Luzero.

Por desgracia todavía no he podido encontrar el ejemplar de El Día donde se publicara el original usado en La Época, y tampoco sé nada de su anónimo autor, quien, como vamos a ver, desde la primera frase andaba un poco descarriado en sus tópicas opiniones sobre el amor de los sefardíes por la madre patria. Veamos ya el texto; dice el autor español de El Dia en la versión aljamiada de La Época:

${ }^{6}$ En su artículo «Relaciones entre la prensa española y la prensa sefardí a finales del siglo XIX: El caso de El Luzero de la Pasensia», en MARTín AsUERo - GERSON ŞARHON Ayer y hoy págs. 38-46: pág. 39 y nota 1.

${ }^{7}$ Con $J$ y con $G$ me refiero a los cómputos juliano y gregoriano, respectivamente. 
«Es de maraviar cómo entre los jiidiós se conserva el sentimiento de su nacionalidad española. Ellos se consideran desterados, non de Palestina, si non de España. El idioma (linguaje) español que hablan más o menos corompido es para ellos una dificultad y non una conveniencia, y sin dubio lo mantienen por ser el linguaje de sus patría.

»Ex́isten en Salonico, la metrópoli (más grande civdad) yiśraelita de Oriente, 33 sinagogas (quehilot) cada una de las cualas lleva el nombre de una civdad española o portugueśa y las famillas que se creen vinientes de algunas de estas civdades habitan en la većindad de la sinagoga respectiva.

»Los nombres de muchas famillas son nombres de civdades de España y Portugal.

»Non es manco en Salonico de 70 mil los jidiós españoles; en Constantinópoli suben a unos 20.000; en Adrinópoli pasan de 35.000; en Filipópoli de 10.000; en Eśmirna de 25.000; Brusa de 15.000; en Erźerum, Trebisisonda, en Tiflis y puertos de la mar Negro, aunque mezclados con los rusos, componen un total de más de 60.000; los de Eífto, Palestina y Siria pasan de 150.000. Asumadas estas cifras con el cálculo de los esparćidos en las localidades del interior de la Turquía evropea y de la Aśia Menor hasta el fondo de la Meśopotamía, ternemos un total de más de 700.000 jidiós españoles que hablan nuestra lingua y conversan en un linguaje más puro que el uśado hoy en España, publican libros y gaćetas españolas, eĉetra.

»Tenemos noticia de dieź gaćetas españolas en caracteres heḅreos: uno de ellos, el más importante, con el título La Época, se publica en Salonico».

Aquí cabe hacer un comentario. Según el texto recogido en la Revista de Geografía Comercial, lo que el original de El Día dice es: «uno de ellos [se refiere a los periódicos] el más importante quizá, titulase La Patria y se publica en Salónica». Debe tratarse de un error del autor español, error que, arrimando el ascua a su sardina, corrigen en la redacción de La Época: según los datos de Gaon $^{8}$, sí existió un periódico La Patría, pero se publicaba en Constantinopla y no en Salónica y ello a partir de 1908.

»Ningún interés podemos abrigar en parecer semitas (amigos de jidiós) o antisemitas, como agora se diće. La sola idea que nos dan estas cośas es el partido que puedría sacar España del elemento iśraelita para ex́ercer su influenza en las cuestiones del Levante. Italia se adelantó a nośotros y buena parte de los intereses que aquea nación se ha creado en Oriente y que non poco han contribuido a darle voto en los consejos evropeos, provienen de yiśraelitas españoles convertidos en súditos italianos o puestos deḅajo el protectorato de Italia. Los jịidiós con los gregos monopoliźan el comercho

${ }^{8}$ Moshe David Gaon, A Bibliography of the Judeo-Spanish (Ladino) Press [en hebreo] (Tel Aviv 1965) núm. 217. 
levantino. Salonico, que es hoy la segunda escala marítima de Levante, y será la prima tan luego que se hará la unión del ferocaril (camino de fiero) macedónico con los feros cariles serḅos y austriacos, Salonico es un riquísimo puerto comercial esencialmente judaico-español.

»Si se trata de estaḅlecer una línea de vapores españoles entre nuestros puertos y los de Levante no faltarían capitales iśraelitas para secundar (ayudar) la empreśa.

»Es indispensable antes de todo la reorganiźación del cuerpo consular en Oriente».

Como vemos, tras la primera frase continúa el autor haciéndose cruces -con perdón- sobre los nombres tan españoles de las sinagogas sefardíes de Salónica y de los apellidos, y hace un curioso cálculo de los que viven por las tierras del Imperio otomano, que cifra en más de $700.000^{9}$. Tras curarse en salud con la frase «Ningún interés podemos abrigar en parecer semitas (amigos de jidiós) o antisemitas, como agora se diće», no sea que alguien le vaya a tomar por lo que no es, continúa poniendo de relieve con todo lujo de detalles los beneficios que España sacaría de aprovechar todo este «amante» potencial económico que vive en Levante, concluyendo con aires triunfalistas:

»Conviene que la iniciativa ${ }^{10}$ con el apoyo (arimo) oficial bušque los remedios de respandir la habla pura castellana y la instrucción española entre los jidiós orientales y lo que es fácil de llevar a cabo, siendo se debe contar con la entuśiasta cooperación de las comunidades iśraelitas. Conviene que los caracteres judaicos desparezcan de las gaćetas y libros judaicos-españoles, y esto se puedrá haćer el día ande la masa de la populación de los iśraelitas se convenza de que el español puede redactarse de diferente manera.

»En Oriente nos está reśervado un mercado literario, el español antiguo y el grego moderno son hoy día los 2 linguajes mercantiles de Oriente. Fomentemos ya la enseñanza, la literatura, la prensa española con la cuala descubriremos nuestro esprito, haremos aĉetar nuestra opinión y haremos valer nuestro prestiĝio en la solución de los proḅlemas políticos orientales».

Hasta aquí el texto español que rezuma prepotencia, dando a entender el autor su convencimiento de que con sólo chascar los dedos los sefardíes iban a

9 Ignoro de dónde sacaba sus datos el articulista madrileño, pero, recordemos que, por ejemplo, M. Franco en su Essai sur l'Histoire des Israélites de l'Empire Ottoman ... (París 1897) pág. 1, recogía la opinión de Théodore Reinach, quien cifraba la población sefardí de la Turquía europea y asiática, Egipto y Tripolitania (Libia) en 314.000 personas y más abajo veremos (aprt. 3) cómo David Fresco cifra en 150.000 los sefardíes hablantes de judeoespañol.

${ }^{10}$ En la Revista de Geografía Comercial se habla de «la iniciativa privada». 
venir a comer en mano de los españoles. ¿Y qué es lo que apostilla el comentarista de La Época?: pues lo siguiente:

Creemos que nuestros leedores meldarán con interés el artículo que precede.

Nośotros traśladimos pocas palabras del oriǵinal y, sobre más, non toquimos del todo a su compośición por dar una preba que non sería difícil por nośotros jiidiós levantinos de meldar y entender el puro español,

y realmente así es, ya que el texto que hemos leído, si bien adaptado a la fonética judeoespañola, nos suena a español y no a judeoespañol y en él aparecen solo seis paréntesis explicativos: linguaje para explicar idioma, mas grande civdad para metrópoli, quehilot para sinagogas, amigos de jidiós para semitas, camino de fiero para ferocaril, ayudar para secundar y arimo para apoyo.

Sigue el colaborador de La Época:

La cuestión de non posedar una lingua regulada con la cuala puedríamos declarar todas nuestras ideas es una cuestión mucho importante por las comunidades judías del Levante. Non hay dubio que es más fácil de amejorear el español que hablamos que de remplazarlo con otra lingua.

Ma el español sería de poco provecho para los raportos comerciales y por el adelantamiento y deśvelopamiento del esprito de progreso entre nośotros. La literatura española nos es desconocida y non tenemos la miśma facilidad de procurarmos libros y gaćetas españolas como tenemos por libros y jornales franceśes y italianos.

Con todo, puede ser que nuestros coreliĝionarios levantinos prefirieran el estudio del español a aquel del francés o del italiano si el goberno de Madrid entiende el grande provecho que ternían el avenir y el comercio de la España con el respandimiento de su lingua y de su literatura entre tantos miles de jidiós levantinos. Ma tenemos poca esperanza que el artículo que publicamos de la gaćeta El Día tenga alguna consegüenza y la España continuará a olvidar a los jidiós que enriquecieron su estado, mientres que los jidiós non olvidan la España que los desteró y los presiguió con toda la crueldad de aquellos tiempos. Los antisemitas debrán pensar un poco sobre esta proba de grande atamiento que los jidiós tienen por la patría que los tuvo en su seno.

Deśearíamos a esta ocaśión hablar del provecho que habría a empiegar caracteres latinos en lugar de estas letras que non sirven que a iśolarmos cumplidamente entre nośotros y impedir toda posiblidad de amejorear nuestro linguaje. Ma es una cuestión mucho importante que merece ser bien tratada. Acodraremos solamente a nuestros leedores que La Época había hecho una proba de publicar ciertos artículos en caracteres latinos y vimos cómo ciertas gaćetas de la capitala que se publican en otras linguas 
empezaron a entrar en cambio de ideas, lo que es siempre provechośo. Ma ya diǰimos que reverniremos una otra veź sobre esta cuestión ${ }^{11}$.

Del texto quiero destacar varias cosas que me parecen de especial interés. El autor echa en falta una a modo de Academia sefardí que regulara la lengua y también señala la facilidad con la que los sefardíes podrían pasarse al castellano -gracias que tal cosa no tuvo efecto, porque algunos de nosotros nos habríamos quedado sin poder ganarnos las lentejas-.

Según se dice en el artículo, los sefardíes desconocen la literatura española, lo que ya sabíamos, y en este sentido sí es una lástima que en España nadie se hiciera eco de lo que el corresponsal español proponía: difundir en Oriente nuestra literatura o al menos remediar esa dificultad señalada por el articulista de $L a$ Época que tenían los sefardíes de los Balcanes para conseguir libros y periódicos españoles, lo que no sucedía con publicaciones en otras lenguas.

Otra cuestión de interés que se aborda tanto en el texto español como en el judeoespañol es el espinoso problema del uso de los caracteres hebreos. El que en el artículo de La Época se defienda tal cambio nos certifica que su autor es Sam Levi, hijo del fundador y director de La Época, Sa'adí Haleví, ardiente defensor de esa idea.

Ya he dejado constancia en otro lugar de cómo los sefardíes no gustaban del cambio de caracteres rašíes a latinos; recuérdese, por ejemplo, el recelo con que se recibe la aparición de El Luzero de la Pasensia con esa grafía ${ }^{12}$; y la misma cuestión se suscita aquí en las palabras del articulista de La Época cuando se menciona el intento hecho por el periódico de publicar así algunos artículos y cómo «ciertas gaćetas de la capitala [...] empezaron a entrar en cambio de ideas», es decir, a discutir expresando opiniones contrarias.

De todas formas y por mucho que no todos los sefardíes lo quisieran, el tiempo y la presión oficial acabaron con el problema de la grafía, pues a partir de finales de 1928, cuando en cumplimiento del decreto de Kemal Atatürk tuvo lugar la drástica reforma gráfica del turco, lengua que pasó a escribirse de caracteres árabes a latinos, los periódicos judeoespañoles de Turquía tienden asimismo a aparecer paulatinamente escritos en estos últimos.

11 Entre la serie de artículos que abordan el tema no hay que olvidar el publicado por «Cragimon» (firma en caracteres latinos) en La Época 25:1225 (3 adar I 5660 / 2 feb. 1900) págs. 9a-b, titulado Una utopía en donde comenta las propuestas de la sociedad La Esperanza de Viena que preconiza el uso de los caracteres rašíes, advierte de las dificultades que el cambio gráfico comporta y aporta ideas de cómo llevarlo a cabo.

12 Vid. al respecto Romero Creación pág. 190. 
Y por último cabe señalar que el redactor de La Época lo tenía muy claro en cuanto a la previsible nula reacción de la administración española, que efectivamente hizo caso omiso de los argumentos de nuestro desconocido autor español.

\section{El RECHAZO A EsPaÑa Y A SU HERENCIA LINGÜísticA VERSUS LA CAMPAÑA de Ángel Pulido}

Muchos de los intentos hechos por los sefardíes de buscarse otra lengua distinta de la judeoespañola reposan en esencia en algo más profundo que en el deseo de acercamiento por parte de los sefardíes más realistas a las lenguas ambientes de los países en los que vivían. En lo que reposa y se sedimenta es en el profundo rechazo que aflora entonces en un amplio sector del mundo sefardí por la lengua que, muy a su pesar y como sucede en los procesos históricos, de forma absolutamente natural, era la suya, es decir, el judeoespañol, que en lo que tiene de español recordaba al sefardí el desgraciado final de su vida en España.

Veamos lo que se dice en El Tiempo 22:20 (21 kislev 5654 / 30 nov. 1893, pág. 216b-c):

Uno de nuestros amigos de Salónica nos escribe esto que siguie:

Israelitas de Turquía.- Expulsados de España por la horiḅle Inqüiśición, nośotros topimos en Turquía mientras el gloriośo reino de sultán Bayaźid II una tierra ĝenerośa que mos aḅrigó bajo sus alas al despecho de la España y de todos aqueos paíśes occidentales que mos ronjaban como parias, hombres proscritos y maldichos.

Nośotros formábamos una casta aparte, menospreciados universalmente por la noḅle acción de no querer abjuurar la reliĝión de nuestros abuelos, reliĝión que espandió en todo el mundo las leis suḅlimes de la humanidad. Nośotros no aḅandonimos la lingua del suelo natal, ma poco a poco, al contacto de nuestra nueva patría, esta lingua fue talmente desformada que no la nominamos más que soto el nombre de judeoespañol.

¡Horible jergonźa que el judeoespañol!

J́ergonźa que nośotros debríamos aḅandonar por eguardo al noḅle país otomano, en el cual mos contamos venturośos de vivir.

Palabras como estas que hemos leído salpican la prensa judeoespañola de la época. Recordemos que en este caso el artículo está fechado en 1893 y ello me suscita una pregunta. Desde finales del siglo XV en adelante los sefardíes quizá no supieran muy bien adónde iban, pero sí tenían muy claro de dónde venían; ¿por qué surge, pues, ahora con tanta intensidad y virulencia la mención y el recuerdo de la madrastra expulsadora? 
Quizá debamos ver en el trasfondo de esa revitalización de la saña antihispánica -siempre latente, pero que aflora muy de tarde en tarde en la literatura sefardí de los siglos anteriores- las conmemoraciones en torno al cuarto centenario de la expulsión habidas en los Balcanes en 1882, es decir, un año antes de publicarse muchos de los textos aquí seleccionados en los que el recuerdo del pasado se reavivó y las conciencias se agrietaron por una herida nunca definitivamente cerrada. Al respecto cabe recordar el «Número especial a la ocaśión del Cuarto Centenario de la venida en Turquía de los judiós de España» que a tales desgraciados avatares históricos dedicó el periódico de Constantinopla El Tiempo (en nisán de 5652) y al que, que yo sepa, nadie le ha prestado especial atención. Indudablemente otros muchos periódicos sefardíes debieron hacerse eco de aquel evento histórico. La búsqueda y análisis de esos textos es una tarea aún no realizada y que deberíamos abordar los especialistas en el mundo sefardí.

Los sentimientos que hacia la madrastra España destilaban un buen número de sefardíes -aunque no todos- se plasman también años después en numerosos artículos que reaccionan contra la campaña de Ángel Pulido. Veamos dos ejemplos contrapuestos: el de un sefardí, Refael Kohén, defensor ardiente del mantenimiento del judeoespañol y dispuesto a perdonar el pasado, y el de otro, Iśac Ferera, que no está dispuesto a hacerlo.

El primero apareció en el periódico de Esmirna El Meseret 8:54 (24 ab 5664 / 5 agosto 1904, pág. 3b) y dice así:

La lingua española.- Antes un poco de tiempo publiquimos un artícolo debido a la péndola de uno de nuestros redactores, el Se" Jośef Romano, y en el cual trataba de la corespondencia y las relaciones que él tiene con el doctor Ángel Pulido de Madrid ${ }^{13}$.

${ }^{13}$ Una carta de Romano agradeciendo a Pulido el envío de un libro figura en Pulido Españoles pág. 71. Allí (pág. 70) el senador dice que Romano era «distinguido profesor de inglés en la Escuela escocesa, redactor del periódico El Messeret y corresponsal de La Época, de Salónica» y publica su fotografía (pág. 204). GAON Bibliography núm. 176, al ocuparse de El Meseret, periódico dirigido por Alexandr Ben-Guiat, no menciona ninguna relación de Romano con ese periódico; pero sí (ibíd. núm. 55) que fue redactor de La Yoź del Pueblo de Esmirna, recogiendo además interesantes datos sobre su colaboración con los griegos en los años 1919-1922 durante la ocupación de Esmirna y su salida precipitada acompañando a las tropas griegas en huida tras la recuperación de la ciudad por los turcos. Por otra parte, en La Época 25:1208 (2 hẹ̌ván 5660 / 6 oct. 1899) págs. 8a-9a, bajo el título Eśmirna se publica una carta de M. Hadjès (el nombre en letras latinas) dirigida a Romano en donde se da un interesante dato sobre su persona: que se había convertido al protestantismo - de ahí que trabajara en la Escuela Escocesa- y que hacía proselitismo entre los judíos esmirniotas, lo que se afirma con estas palabras «... siendo él, que es protestante, no tiene dingún hecho en estos lugares [se refiere a la sinagoga], visto que él haće su oración en la iglesía de la cuala él es pagado por recoǵer algunos jiidiós en el día de šaḅat santo y 
El Se" Refael Kohén ${ }^{14}$ de nuestra civdad tuvo escrito una letra rogando al senator español de mandarle uno de estos libros, y en curso de esta semana el Se" Kohén recibió un libro y un jurnal. A esta ocaśión él nos manda un chico artícolo onde es dicho todo lo que el Se" Romano ya tuvo dicho en el suyo. Todavía, publiquimos el último paragraf de su artícolo, ansí que un entrefleto quitado de uno de los escritos del Se" Pulido: «iNo seáš deśgraciados donde reśidíš (moráš) y amad a vuestra patría actual! ¡Dioś bendiga vuestra noḅle acción y premie vuestra lealidad!».

¡Esto es justo! Nośotros, como indulǵentes que fuimos con todos los que obraron injustamente con nos, debemos también serlo con esta España que nos hiźo tanto sufrir. Malgrado todo, nośotros conservamos aún el español como nuestra lingua madre y nos olvidamos de lo pasado en acodrándonos de lo preśente... Esta es nuestra satisfacción. «En źijrón larišonim» diće nuestra Ley ['No hay memoria de las cosas pasadas', Ecl 1:11].

A la vista de las buenas relaciones de Kohén con Pulido, no parecen ser irónicas sus palabras, que presuponen la muy cristiana idea de poner la otra mejilla.

Pero hay algo que quiero resaltar. Las palabras citadas de Pulido tenían un matiz diferente del que se desprende de su formulación en judeoespañol. La frase, que según el propio Pulido dice formaba parte de un artículo suyo en el periódico España ${ }^{15}$, se reproduce en Españoles (pág. 213), y en versión española dice: «¿No sois desgraciados donde residís y amáis a vuestra patria actual? Dios bendiga vuestra noble acción y premie vuestra lealtad». Con ello lo que el senador hace es alabar a aquellos sefardíes que consideran al Imperio otomano como su patria y que se mantienen fieles a ella; sin embargo, del cambio de no sois a no seáš, con valor de imperativo, y el de las interrogaciones por admiraciones, parece desprenderse que los lectores sefardíes hubieran entendido otra cosa, a saber: «no sigáis siendo desgraciados allí donde vivís, y amad a esta patria (España) que en la actualidad os abre los brazos». Ello me suscita una pregunta: ¿hasta qué punto los sefardíes de los Balcanes entendían correctamente el español de España? Se trata ésta de una cuestión cuyo estudio, si ello es posible, deberíamos abordar algún día.

por haćerlos asistir a la oración especiala hecha en este día», y más adelante «... siendo ellos son jidiós y no convertidos como lo es él» (pág. 8b).

${ }_{14}$ Aparece varias veces mencionado entre los corresponsales de PuLIDo en Españoles (vid., por ejemplo, págs. 293 y 452-453, con una foto suya).

15 Vid. Pulido Españoles pág. 209. 
Siguiendo con lo nuestro, bien distinta es la respuesta de Iśac Ferera a la dicha campaña pulídica, quien, dando un soberbio varapalo al senador, dice en un exquisito judeoespañol que nos lleva a lamentar que quien así escribía pensara que su lengua era un jargón. El texto apareció en el periódico El Tiempo de Constantinopla en 1904 (32:89, 30 ab 5664 / 11 agosto 1904, págs. 974c-975c) y dice así:

La lingua judeoespañola y Se' Pulido.- Los lectores del estimado periódico El Tiempo fueron ya informados de la llamada que Se' el doctor Ánĝel Pulido, senador español, tuvo aderezado a los joornales El Avenir y La Época, tendiendo a criar nuevos ataderos de amistad y de confraternidad entre los judiós del Oriente y los españoles, sus viejos compatriotas. Se' Pulido recibió la repuesta que su fervente y calurośa llamada suponía en ella misma.

Es curiośo de remarcar que en este eterno viaje de las personas y de las cośas en la interminable succesión de los siglos y de las ĝeneraciones, los hechos históricos, los acontecimientos sociales se encontrarán a traverso las épocas diferentes... Pueblos y naciones enteras que parecían aḅandonarsen, olvidar mismo sus ex́istencia, se encontrarán un día mientras el curso de este grande movimiento rotativo que haće nuestra planeta al torno del sol y de ella misma. Ellos se miran con curiośidad, la fuerza evocatriz de sus imaǵinación salta a traverso las generaciones pasadas y descubre allí la solución de una enigma doloriośa. Es justamente este caśo que viene de producirse después de más de cuatrocientos años de olvido y indiferencia. Esto es lo que se puedría llamar la ironía de las cośas. Dunqüe, el tiempo ya vino onde la España que nos desterró, que nos expulsó, dando cabo ansí a las mil crueldades y suplicios de todo género a los cuales nuestros antepasados fueron sometidos, esta misma España por la gloria de la cual nośotros contribuimos anchamente, nos tiende sus brazos y nos llama con tanta ardor que nos haće saltar las lágrimas a los ojos, como si hubiéramos reconocido en ella una hermana perdida y que se toparía después de munchos días de angustia. Sin duda, nuestro corazón no puede ser enteramente estranjero a este movimiento de simpatía. Nuestras almas no mancan de viḅrar de emoción al son de esta ỵoz lejana tan llena de recuerdos esmovientes. Sí, ma por cuanto la emoción sea fuerte, esto no es que la luź pasajera y fuǵitiva de un relámpago, o el ruido sordo del golpeamiento de dos nubes cargadas que se encontran, ma no tan fuerte por que se puede producir el rayo ni mismo la electricidad. El ruido de un acontecimiento cruel puede ser más dolorośo que el acontecimiento él mismo. La dolor es más aguda y en consecuenza más sensible, porque ella se enraiga con el tiempo hasta el fondo de la alma y parece dormir allí, cuando una sacudida violente viene revivirla y despierta en nos un dolor proporcionado a la distancia que separa el recuerdo de nośotros. 
La llamada de Se' Pulido no puede que provocar nuevos sanglutos, nuevas lágrimas, en haćiéndonos acordar los males, las tribulaciones donde nośotros fuimos infliǵidos injustamente. Cuanto a la propośición que él nos haće de cultivar la lingua española, que, diće él, nos aseguraría un avenir a nośotros judiós del Oriente, Se' Pulido parece haber pretendido ${ }^{16}$ y negliǵido estos puntos.

El magnífico alegato de Ferera se organiza en los siguientes cinco puntos:

1.- Dećir que la España puedrá asegurarnos un avenir es pretender que los judiós del Oriente no están contentes de sus suerte, que la benevolente y hospitaliera Turquía no puede mantenernos, no dispone de los medios necesarios a la realiźación de una vida opulente y mismo honesta.

2.- Se' Pulido, más cerca de la España que de la Turquía, naturalmente, se haće una idea enteramente otra de los dos paíśes. Lo cercano le aparece muy grande, mientras que lo lejano le aparece microscópico.

3.- Los israelitas de Turquía no pueden profitar de sus conocencias en la lingua española que en emigrando. Ansí que las estadísticas lo preban, los judiós de Turquía que emigran forman el más chico número, y esto en grande parte por no conocer la lingua del país. Encorajarnos a emigrar a las contradas leǰanas es dećirnos: «Dejaad vuestra caḅaña y venid recoltar aquí el oro y la plata». Nośotros preferiríamos, por seguro, nuestra choza bien aerada del aire de la liḅertad, aclarada por el sol salutario de un réǵimen humanitario, de igualdad de derechos.

4.- En admitiendo que la literatura española contenga treśoros inexplotados, esto no sería profitable que a las personas sabias, como rabí Abraham Danón ${ }^{17}$ o rabí Ḥayim Bijarano ${ }^{18}$, los cuales, sin que Se' Pulido se adelanta-

${ }^{16}$ Quizá con el sentido del adj. fr. prétendu 'supuesto'; Joseph Nehama, Dictionnaire $d u$ Judéo-espagnol (Madrid 1977) recoge la voz pretendído también como adj. que traduce 'soidisant, prétendu'; por el «y negliǵido» que le sigue, aquí no parece tener el sentido de esp. pretender, que se usa correctamente un poco después.

17 Rabino y erudito sefardí, que, como Hayim Bejarano, mencionado a continuación, fue miembro correspondiente de la Real Academia de la Lengua Española. A él se debe la fundación del Seminario Rabínico, sito primero en Adrianópolis y más tarde en Constantinopla, que funcionó hasta su emigración a París en 1917. Sobre él puede verse la bibliografía que recojo en mi libro Entre dos (o más) fuegos (Madrid 2008) cap. 8 nota 59.

${ }^{18}$ Se trata de Hayim (Enrique) Bidjarano (1850-1931), Gran Rabino de Bucarest y más tarde de Constantinopla y notable defensor del judeoespañol; en su articulo «Los judíos españoles de Oriente: lengua y literatura popular», Boletín de la Institución Libre de Enseñanza 9 (Madrid, 1885) págs. 23-27: pág. 27 culpa del deterioro de la lengua a la confusión que provoca la lectura de los textos escritos en letra raší. El original manuscrito que dio lugar a ese artículo, una carta dirigida por Bejarano a Joaquín Costa, se conserva en el Archivo Histórico Provincial de Huesca: Archivo Joaquín Costa, Caja 95, carp. 28.3. 
ra o los previniera, se harían un deber de cultivar las letras españolas si ellos topaban, portanto, que la pena valía la candela. Cuanto a la multitud, ella quedaría siempre estranjera a este movimiento literario, visto el menester urǵente de estudiar lo que es útil y no lo que es agradable. A punto de vista de utilidad, los israelitas del Oriente no preferarían estudiar la lingua español. Bien entendido, ellos se descargarían de esta lingua si no les era inauculada, por ansí dećir. Si esto era un vestido, él sería trocado desde muncho tiempo. Y pues, ¿qué manera Se’ Pulido entiende realiźar este paradoxo?

¿Sería posible de adoptar, por serle agradable, una nueva metoda por enseñar el verdadero español a nuestros coreliĝionarios? Se' Pulido se il·luśiona que su español nośotros lo conservamos intacto. Él tiene raźón, siendo él lo oyó de la boca de Se' Bij̄arano ${ }^{19}$. Sería muy judiciośo de meterlo en contacto un minuto con el público, haćerle sentir el idioma sea-dicho español que nośotros hablamos. Es bien seguro que él caería de la altor de sus il·luśiones.

En desparte los yierbos turcos que se introducieron en nuestro linguaje popular, los yierbos españoles ellos mismos son munchas većes conjugados en la forma turca, como munchos yierbos turcos se conjuguan en la forma español.

¿Qué manera haćer por que el púḅlico pueda servir la cauśa de Se' Pulido, muy preocupado por los interesos de su patría y muy poco preveente por los nuestros?... Nos refuśamos a creer que hasta ahora alguno haiga tenido la idea de profitar de la lingua española sobre el suelo de la España y sobre otras partes. Si esto se puedía haćer, los pocos emigrantes no harían mejor que diriǵirsen verso el país natal de Se' Pulido... La estadística no parece, todavía, darle raźón... ¿Es aquí en Turquía que nośotros meteremos a profito la lingua española? Que Se' Pulido nos recomende los medios y nośotros nos haremos un deber de aplicarlos. ¿Qué manera el español puedrá suplear aquí las otras linguas de las grandes naciones? ¿A cuálo puede sernos útil este factor si él no es multiplicado por otros factores?

5.- Se' Pulido negliǵe también que una comunión de interesos sociales no puede ser estaḅlecida entre los dos paíśes con la intervención de un cierto número de israelitas conociendo al fondo el idioma castellano... Es verdad que sultán Bayaźid 2 consideró los israelitas como un factor necesario a la extensión del comercio otomano..., ma hoy las cośas trocaron. Los acontecimientos políticos y económicos cambiaron la figura del universo. Los menesteres, los interesos de las naciones no son hoy los mismos que aqueos de cuatrocientos años antes.

El texto es tan claro y enjundioso que no requiere comentario alguno.

19 Tal idea la recoge Pulido Españoles pág. 182. 


\section{El tURCO COMO SOLUCiÓN}

Sabemos que muchos sefardíes estaban ansiosos por sacudirse de los hombros la lengua judeoespañola que se siente como un yugo del pasado y un lazo de unión a una historia desgraciada. Y también sabemos que en lo que difieren los intelectuales sefardíes es en qué hacer con el judeoespañol, barajándose las varias opciones encontradas que he esbozado arriba: 1) dejarlo como estaba; 2) purificar y espurgar la lengua de elementos foráneos para aproximarla al español de España, aconsejándose -ya lo hemos visto- como primera acción a emprender el prescindir de los castizos caracteres rašíes y usar los occidentales; y 3) otra más drástica: olvidarse del judeoespañol y raerlo de la faz de la tierra para sustituirlo por otra lengua: francés, hebreo o alguno de los varios idiomas locales al alcance.

En relación con el turco y en las fechas en las que nos movemos, casi todos los que intervienen en la polémica parecen estar de acuerdo, como bien lo señala Lochow-Drüke ${ }^{20}$, en la urgente necesidad de conocer la lengua del todavía Imperio otomano; pero en lo que difieren es, por un lado, en considerar que esa lengua debe suplantar al judeoespañol y que éste debe ser erradicado de «la faz de sus mentes», y por otro, en creer que ambas lenguas deben y pueden convivir. En los textos que siguen veremos reflejadas ambas posturas.

Ya he dejado constancia en otro lugar de la poca aceptación que tuvo un primer intento hecho en 1867 de publicar un periódico en turco, el Šarkií de Constantinopla, por mucho que estuviera escrito con caracteres rašíes ${ }^{21}$. Por su parte M. Franco ${ }^{22}$ menciona otros dos periódicos -Zeman (1872) y Ceridie Tercume (1876) - igualmente escritos en turco con caracteres hebreos, señalando el fracaso de tales intentos por el desconocimiento que el público tenía de esa lengua.

Pero con el paso del tiempo y aún antes de la definitiva disolución del Imperio otomano son cada vez más numerosos los artículos periodísticos que emprenden la defensa del turco como lengua única de los sefardíes.

\subsection{Opiniones de 1893}

En la rúbrica «Israelitas de Turquía» del número ya citado arriba de El Tiempo de 30 de noviembre de 1893 (22/20, 21 kislev 5654, pág. 216b-c), el autor, que se firma «Un patriota», continúa con las siguientes palabras:

\footnotetext{
${ }^{20}$ Lochow-DrüKE «Campaña» pág. 66.

${ }^{21}$ RoMero Creación pág. 190.

${ }^{22}$ Essai págs. 278 y 282-283.
} 
[...] ¡Horiḅle jergonźa que el judeoespañol! J́ergonźa que nośotros debríamos aḅandonar por eguardo al noḅle país otomano en el cual mos contamos venturośos de ỵivir.

Yo me explico. La ley primordial de la concordia entre los diferentes pueblos de una misma nación es la asimilación, en la accepción la más larga de esta expresión. La asimilación de lingua y la asimilación de uśos. El primer caśo mos ocupa hoy.

La asimilación de lingua rendería fieros nuestros compatriotas otomanos, todo en rindiendo inmensos servicios a la cauśa de los israelitas del Imperio. Si nośotros adoptamos la lingua turca como lingua nacional, ¿qué nueva era de prosperidá no se abrirá, dunqüe, por el Imperio del cual nośotros somos súditos fieles? ¿Cuántos postos distingüidos en todas las ramas de las administraciones no veremos nos ocupadas por israelitas?

El amor por la patría se recrecerá en nuestros corazones y pagaremos ansí un tributo de reconocencia a la valiente nación otomana a la cuala nośotros, israelitas de Turquía, debemos esta dulce ex́istencia.

¿Y por qué no puedríamos nos remplazar el jerigonźa judeoespañol por la lingua turca? Yo someto esta cuestión a los jornalistas judiós de Turquía en conjurándoles de abrir una campaña activa a fin de traer una solución a este proḅlema que preocupa munchas concencias y contriḅuir ansí por sus parte el pronto relevamiento de los israelitas de Turquía.

Contestando a la propuesta que acabamos de ver, pocos días después y en el artículo «El judeoespañol», se publica en El Tiempo 22:23 (2 tebet 5654 / 11 dic. 1893, págs. 247b-249a) una defensa del mantenimiento del judeoespañol:

Se' redactor del jornal El Tiempo, hy"v:

Con un ỵivo plaćer meldí en la hoja del 21 kislev páǵina 216 las palabras de un patriota de Salónica, las cualas él adereza a sus conhermanos de la Turquía. Seguro es que este se' es lleno de patriotismo verdadero y conoce a fondo las escrituras santas. El profeta Yirmiyahu diće: «vediršú et šelom ha'ír ašer higleti etjem šama vehitpalelú ba'adah el H', ki bišlomah yihyé lajem šalom» ('y bušcad la paz de la ciudad a la cual vos lleví en cativerio y haćed oración por ella a H', porque en su paź vośotros ternéš paz', capítulo 29 pasuc 7).

Por esta raźón, es el más santo deber de cada judió de enỵeźar la lingua del país. Hablar, meldar y escribir correctamente, esto es por nośotros no solamente un obligo de la parte del goberno, ma también un santa ley, como ya diǰo en los tiempos antigos el il·lustre talmudista mar Šemuel: «diná demaljutá diná» ('la ley del goberno tiene valor por nośotros los judiós como un din de nuestra santa ley'). Dunqüe, se entiende de suyo que cada uno de nośotros debe asimilarse enteramente a los uśajes del país en el cual yive y del cual tiene su mantenimiento. 
Es, dunqüe, sin duda (safec) que preme a nośotros perfectamente conocer la lingua del país y acomodarmos a los uśajes del país si ellos no son contrarios a los deberes que debemos acomplir como judiós.

Ma, de otra parte, no estó de acordo con el honorado se' patriota de Salonico en su deśeo que se anule enteramente onde nośotros la lingua española, aunque ella no es conservada puramente onde nośotros.

Tenemos dos raźones por nuestra opinión. La prima es que esta lingua española se llama onde nośotros la lingua judaica. Más de 400 años hay que conservamos esta lingua hermośa, ¿y agora debríamos quitarla? La historia de los judiós en la España es la más gloriośa que todas. En la España se toparon los más grandes sabios y poetas que tenemos; más: también en esta tierra de la España los judiós ocuparon los más altos postos en el goberno y no de menos, como diće el profeta: «hišlij mišamáyim ereŝ tiféret Yisrael» (Ejá [Lam] 2:1: ['echó de los cielos a la tierra la hermosura de Yisrael']).

Por esta raźón deśeo yivamente que conservemos nośotros y nuestras criaturas esta lingua de nuestros santos abuelos 'a'h, que sea un señal y en miśmo tiempo un acavidamiento que non olvidemos nunca la grandeźa y la noḅleźa de nuestros abuelos y que restemos fideles oḅservadores de nuestra santa Ley, a fin que el Dio todopoderośo mos protejga.

Esta segunda raźón es de una natura histórica y toca también nuestros sentimientos. Ma como ya diće la Guemará, «lo nitená haTorá lemalajé hašaret» ('la Torá non fue dada por los ángeles del servimiento'). Conocer la lingua española es también de un provecho práctico. Esta lingua es aparientada con las linguas francés, italiano, español puro, portugal y rumano $^{23}$. Y sí como estas linguas son menesterośas por el comercio en el mundo entero, la conocencia de esta lingua miśmo en nuestro jargón tiene munchos provechos.

Por esto digo con las palabras de Cohélet: «tob ašer teehoź baźé vegam miźé al tanah et yadeja ki yeré Elohim yeŝé et kulam» [Ecl 7:18] ('bueno es que trabes de esto y también de esto non apartes tu mano, porque el que teme del Dio sale de todos').

Sofía, el primo día de Hanuká 5654. El Gran Raḅino de Bulgaría: Dr. Mordejay Grinvald. El secretario: Nisim M. Aseo.

En esta carta, cuyo primer firmante y defensor del judeoespañol es nada menos que un rabino asquenasí, se ponen de relieve varias cosas. En primer lugar,

${ }^{23}$ Una idea semejante ya se expresaba en el artículo sin firma «La cuestion de la lengua para los Isr-tas espanoles en la Turquia», aparecido en El Luzero de la Paciencia (ahora así escrito) 3:29 (14 tišrí 5649 / [J] 9 / [G] 21 sep. 1888) pág. 407 en el que, amén de hablar en favor del hebreo, también se aboga por el español, «esta lengua hermosa que serca 47 miliones la hablan», argumentando que «conociendo ese lengua Espanola vera, sera muy facil de conocer la lengua latina, italiana, portugala, francesa, romana, etc.». 
se está de acuerdo con lo obvio: que hay que aprender la lengua del país. Pero en defensa del mantenimiento del judeoespañol y lo que no es habitual en este tipo de textos que fijan su exclusiva atención en los trágicos períodos del final de la presencia judía en España, se recuerdan las glorias pasadas de los judíos en AlÁndalus y en los reinos hispanos medievales. Y además, lo que tampoco suele ser corriente, se arguye el parentesco del judeoespañol con las varias lenguas romances, lo que sin duda abre al sefardí muchos posibles contactos.

La réplica es inmediata y en el mismo número de El Tiempo contesta a continuación el director del periódico, David Fresco, con las siguientes enérgicas y rotundas palabras:

Yo so naturalmente de acordo con el sabio Gran Rabino de Bulgaría en lo que concerna la conocencia de la lingua del país. Digo «naturalmente» porque esto es una verdad muy simple que no admite ninguna discusión. Es la lingua que establece la comunidad de pensamientos y de sentimientos entre los miembros de un Estado y que constitúe uno de los principales ataderos de la nacionalidad.

Peró, en lo que toca el judeoespañol, yo so de una idea diametralmente opuesta, y esto no por una simple convicción personal o un espíritu de

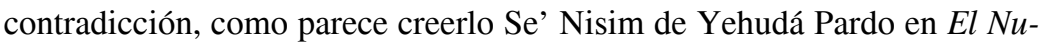
velista de Esmirna. Yo creo que mi idea es sostenida por argumentos muy fuertes, cas̀e irrefutables.

Nos es imposible de conservar este idioma por consecuenza de esta ley que no pueden conservar un objeto del cual no pueden tirar ningún profito. Esta ley reina en el orden fíśico y en el orden moral de las cośas de este mundo. La infalible natura se doḅla delantre esta ley. Tal animal perteneciendo a una cierta familla, manca de un órgano en una otra contrada y bajo un otro clima y es dotado de un órgano en más en un otro lugar, y esto porque este órgano es necesario aquí o inútil allá.

El judeoespañol nos es, no solamente inútil, ma mismo dañośo en nuestra «vida social». Insisto sobre estos yierbos porque las relaciones íntimas entre la comunidad de una fracción de la populación de un Estado no constitúe la vida social. Entre los miembros de la comunidad judía, quero dećir entre los 150 mil israelitas de Turquía que hablan el judeoespañol, este idioma puede servir de alguna cośa, siempre por nuestras relaciones íntimas y nunca por nuestra «vida social». A meśura que los principios modernos penetran en las populaciones del Imperio, a meśura que las viejas fronteras separando los miembros de diferentes razas y reliĝiones desparecen entre nośotros, la utilidad del judeoespañol, mismo por nuestras relaciones íntimas, mengua considerablemente y él empeza a devenir de más en más dañośo. Los israelitas españoles empezan a no servirsen más, como un tiempo, de este idioma como un medio de relaciones. 
Todo efecto tiene su cauśa; el uno se explica con el otro: por raźonar sanamente sobre un efecto, cale bien conocer la cauśa. Queren purificar, simpli[fi]car o españoliźar nuestro español corompido; es como querer melećinar una enfermedad. Peró, un médico debe bušcar la cauśa de la enfermedad por pueder melećinarla. Nuestro español, un tiempo tan puro, fue corompido. ¿Por qué, por cuál cauśa? Por esta ley inmutable que no pueden conservar un objéto del cual no pueden tirar ningún profito. Mientras los primeros tiempos del aribo en Turquía de nuestros abuelos de España, nośotros pudimos conservar la lingua español en una cierta pureźa y ciertos autores como Mošé Almošnino (autor del Reǵimento de la vida) ${ }^{24}$ y otros pudieron escribir libros que merecerían de ser coronados de la Academía de Madrid. Esto pudo continuar mientras un cierto tiempo, y esto por 2 raźones: el espíritu conservator de los judiós y la vida política. Mientras munchos años, unos cuantos siglos, las diferentes comunidades reliĝiośas del país yivían de una vida excluśiva, sin raporto entre ellas, una especia de estados dientro de un otro estado. Las ideas modernas, los principios sociales se espandieron en el país, y esta vida de aiśolamiento empezó a desparecer y cambiar de condiciones. Alora la lingua español empezó poco a poco ser aḅandonada, a no ser cultivada, y ella se corompió, seña de vejez, seña de muerte. Sí, de muerte, porque una lingua que no es entretenida, alimentada de sustancias nutritrivas y necesarias a su economía, debe morir. Yo rogo a aqueos que son de una opinión contraria de no olvidar que una lingua que es solamente hablada y no escrita no puede nunca yivir.

Escribir en esta lingua, ¿sobre cuálo? ¿Sobre las ciencias, las letras, los artes, la industría, la filosofía? ¿Para quén? Mi hijo o el vuestro que aspiran a la vida, que deben luchar por la ex́istencia, ¿va estudiar en nuestro jerigonźa o en el puro castellano la medicina, el derecho, las letras o las otras conocencias indispensables por la vida? Atorgad que esta idea es riśible. No pretendemos purificar internamente esta idioma, dićen algunos como Se' Pardo, peró renderla un poco más simple, más entendible, más limpia. No sé en fin a cuálo. Si era admitido de creer que hay vaćío en el mundo, es solamente en esta demanda que él ex́iste.

No entiendo por cuálo se esmoven tanto sobre la suerte del judeoespañol. ¿Es él tan diño de intereso y de compasión este jerigonźa hablado por un puñado de personas? ¿Rendió él munchos servicios al judaísmo de Turquía? ¿Crió él una grande literatura? Es posible que haiga dos historias

${ }^{24}$ Sobre la vida y obra de Mošé Almosnino (Salónica 1518-1580) puede verse Pilar Romeu, Crónica de los reyes otomanos (Barcelona 1998); vid. también su artículo «El sueño premonitorio de Moisés Almosnino sobre Yosef Nasí en el Tratado de los sueños (Salónica 1564)», Sefarad 64 (2004) págs. 159-193. Sobre la obra mencionada vid. John M. ZemKe (ed.), Moshe ben Baruch Almosnino, Regimiento de la vida, Tratado de los suenyos (Salónika 1564) (Tempe, Arizona 2004). 
del judaísmo, la una que yo conozco más o menos y la otra que yo ignoro cumplidamente. En aquea que yo conozco no vide sobre la ecena, durante un longo periodo de tres siglos, figurar el judaísmo de Turquía, este judaísmo que tiene por órgano el famośo jerigonźa judeoespañol.

Dejemos de una parte, amigos míos, la sensibilidad y el sentimentalismo y siguiamos las leis de la yelada raźón, de la infalible y impecable lóǵica. La conservación del judeoespañol es imposible porque él no nos es más de ninguna utilidad ni por nuestras relaciones íntimas ni por nuestras relaciones sociales, y él fue, es y será una de las principales cauśas que el judaísmo de Turquía no haće progreso según él debía haćerlo.

Él debe morir. ¿Cuándo?, yo no puedo preciśar el tiempo, porque una lingua no muere súbitamente como un simple criado mortal. Haćer esfuerzos por melećinarlo es inutil y dañośo al judaísmo.

Repitamos una vez más: el alegato de Fresco, en muchos casos demagógico, como cuando pretende ignorar todo lo mucho que durante siglos habían producido los sefardíes, está expresado en un magnífico judeoespañol, esa lengua que según él «es solamente hablada y no escrita» (?): ¿en qué lengua pensaba Fresco que se estaba expresando?

Los siguientes dos textos aparecieron en El Tiempo 22:27 pocos días después del anterior (16 tebet 5654 / 25 dic. 1893, págs. 293a-294b). En el primero, firmado por Sitrí Haleví (probablemente Sam Levi) el 11 de diciembre de 1893 (2 tebet 5654), tras propugnarse la necesidad de conocer turco, quejarse de que los que conociendo tal lengua no hacen nada por desarrollarla entre sus correligionarios, y abundar en que el judeoespañol resulta ineficaz para expresar las ideas científicas del momento, se aconseja, sin embargo, mantener esta última lengua y adoptar paulatinamente el alfabeto latino:

El judeoespañol.- [...] La lingua del país cale aprenderla, posederla y cultivarla. Desfortunadamente, los que la poseden a fondo o a bastanza no la cultivan. Para inculcarla cale meldarla. ¿Por qué aqueos que la poseden no publican una gaćeta por los interesos del judaísmo?

Tanto el reverendísimo doctor Grinvald como el Se' Pardo [...] tienen raźón, malgrado que sepan [sic] en entípedas en esta ocaśión.

¿Cómo se puede explicar al padre de musiú Chatatú ${ }^{25}$, haġuebir hameromam, «la precisión de los l'eqüinoxios» ${ }^{26}$ en nuestro linguaje corompido? Y

25 Escrito ג'גטטט, que no sé si he vocalizado bien.

26 Entre comillas en el original. La palabra está escrita ליקואינוקסייוס, y Dora Mancheva y Aitor García Moreno me vienen a aclarar lo mismo y a ambos les agradezco sus comentarios: en el fr. l'équinoxe 'equinoccio', el artículo ha llegado a formar un todo conjunto con el sustantivo, de ahí que el autor haga preceder la palabra del artículo los. 
cómo haćerlo penetrar al guebir ha'elión ${ }^{27}$ aḅonado a la gaceta del paroxitón y del proparoxitón en nuestro jerga?

Para conciliar el eruditísimo señor raḅino con el Se' Pardo [...] cale aḅandonar el alfaḅeto actual remplazándolo con el latino, alfaḅeto natural de la lingua española. Creo también que nuestros padres en la España se servían del alfabeto latino y no del solitreo.

Este deśastre nuestro es típico: en Alemania, en Austría y miśmo en Francia hay judiós que hablan y escriben en yudesco o yidiš daitš; en Rumanía los turquinos hablan nuestro jerga y los aškenaśim el yudesco.

Cuanto a la parientez de nuestro linguaje corompido con el rumeno, con toda la veneración que debo al doctor y eruditísimo Gran Raḅino de la Bulgaría, no estó de acordo. ¿Por qué? En rumeno «una suta unspreźeche; doźegui chingui» quere de[ćir] '111' y '25'; «merĝem la plimbare» quere dećir 'vamos a caminar' ${ }^{28}$, vejayoŝ'é. Ya mo la pasamos, dunqüe, de esta parientez y recibimos las condolienzas que nos renviene ${ }^{29}$ anticipadamente por esta non parientez.

Filologuía.- Por mi desventura no meldí la prośa del Nuvelista de Esmirna. Kaparat 'avonot ${ }^{30}$.

Concluśión.- Aḅandonar nuestro jerga es cośa humanamente imposible. Cale gradualmente amejorearla y eventuelmente perfeccionarla y a tal escopo cale adoptar el sistema de nuestros padres, «ma'asé abot ya'asú banim» ['lo que han hecho los padres harán los hijos'], en introduciendo el alfaḅeto latino con muncha lentor, a poco a poco. Y ansí las gacetas publicarían un folletín con alfabeto latino sacado de un libro. Y un día aribarán, puede ser, a puḅlicarla entera. Ahora trenta años no había más que una escuela en Cušta, y“E”a, ahora hay más de 20 y no bastan. La lingua española no es muy vaste ni muy rica, pero es suave, linda y priva [sic] de cacofonía.

Bromas aparte del periodista sobre el rumano, encontramos aquí una idea importante: que, como ya lo demostraron sus antepasados, una lengua tiene en sí misma capacidad para ponerse al día.

La segunda de las cartas remitida desde Dresden al día siguiente de la anterior (12 dic. $1893^{31}$ ) está firmada por «Un esmirniota patriota y deśeando el

${ }^{27}$ La expresión está formulada medio en judeoespañol (al) y medio en hebreo, donde sería hagiuebir ha'elión (hb. הגביר העליון) 'el excelso notable'.

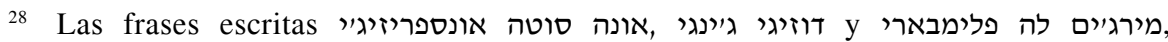
respectivamente; cfr. rm. «una sută unsprezece» '111', «douăzecisicinci» ' 25 ', y «mergem la plimbare». Agradezco a mi amigo Constantin Bompa tales precisiones.

${ }^{29}$ Que debería ser pl. revienen.

${ }^{30} \mathrm{Hb}$. כque nos sirva de) sacrificio expiatorio por nuestros pecados’, en este caso con indudable intención irónica.

${ }^{31}$ Probablemente por error se dice 1892. 
bienestar de sus coreligîionarios», quien, como Fresco, se muestra partidario de adoptar el turco como lengua de la nación sefardí y da varias recetas sobre cómo implantarlo, entre las que destaca la inmersión lingüística en las conversaciones privadas e incluso en las escuelas comunitarias o talmudé Torá (todo esto nos suena mucho a los españoles de ahora y según parece es verdad eso de que no hay nada nuevo bajo el sol; creo que estos textos deberían leerlos, para tomar buena nota, los encargados del sistema educativo de algunas autonomías de esta que, para no levantar ronchas, prefiero no llamar España sino Piel de Toro):

A Se' David Fresco, director del jornal El Tiempo:

Desde unos cuantos días yo leo en su estimado diario diferentes artícolos sobre la cuestión del judeoespañol hablado por los israelitas de Turquía. Su corresponsal de Salónica propone de aḅandonar esta lingua y de adoptar la lingua turca, la lingua del país. Esta propośición me parece la más justa y es por nośotros un deber patriótico de adoptarla.

No es por la primera vez que esta cuestión fue discutida en la prensa judía. Usted, Se' Fresco, se tuvo ocupado munchas većes de ella, y otros siguieron su ejemplo. Pero hasta ahora no indicaron, me parece, el modo de reśolver este proḅlema. Permítame, se' redactor, de emitir mi humilde opinión en esta discusión.

Los jornalistas deben ocuparsen los primeros de esta cuestión de importanza capital. Ellos debrían invitar los hombres competentes y declarar sus opiniones, preśentar una solución y indicar la manera de realiźar las propośiciones que ellos pueden haćer. Es esta manera que proceden en Europa en todas las cuestiones que interesan el público. Son los jornales que toman la iniciativa de formar una especia de controversia pública. Se entiende que cada uno debe oḅservar las leis de la justa crítica, escribir sin pasión, con imparcialidad, sin ferir el amor propio de ninguno.

Yo so de la idea que los judiós de Turquía que hablan el judeoespañol deben, si ellos queren adelantarsen, adoptar la lingua del país. Yo me permito de indicar los procedimientos siguientes que me parecen prácticos.

1.- Formación de una sociedad especial por haćer la propaganda de la lingua turca entre los israelitas del país. El comité central debrá ser en la capital y él formará comités locales en las provincias. Superfluo de dećir que los hombres componiendo estos comités deben ser hombres competentes.

2.- Esta sociedad debrá haćer todo su posible por que la baśe del enseñamiento en las escuelas judías y mismo en los t’T sea en la lingua turca. El esencial es la escuela. Los hijos en engrandeciéndosen se habituerán con esta lingua y se servirán de ella en sus vida doméstica.

3.- Puḅlicar liḅretos especiales en lingua turca tratando de cuestiones que interesan el judaísmo y haćer todo lo posible por que los judiós conversen en esta lingua. 
Hay aínda munchas meśuras que los comités puedrán tomar. Yo reconozco que la obra no es fácil, pero ya saben que en todas las obras los empecijos son muy difíciles. En diez a vente años puedrán aribar al escopo deśeado y el judeoespañol que no nos es de ninguna utilidad será aḅandonado, si no enteramente, al menos en partida.

Los judiós de Turquía, en adoptando la lingua turca, renderán servicios muy importantes al país tolerente y aclarado en el cual ellos son venturośos de habitar, y el judaísmo ocupará una pośición brillante.

A todo ello contesta «La Redacción»:

Nos parece que es ya tiempo de meter una defensa (detenimiento) a este torrente de artícolos que inunda desde unos cuantos días las colonas de nuestro diario. Toda esta discusión nos parece, que nos perdonen la expresión, un fuego de paja: él echa esplandor, quita muncho fumo, sin dar una calor durable y benéfica.

Los diferentes médicos que se ofrecen ĝenerośamente a melećinar la enfermedad de la cual sufre el judaísmo de Turquía son de diferentes escuelas y nulamente de acordo sobre el diagnóstica. El uno cree que se trata de una fiebre proviniendo de safañones, mientras que el otro sostiene que se trata de una meninǵit. El uno es de la escuela de Pastör ${ }^{32}$, el otro de la escuela de Peán ${ }^{33}$. Cuanto al tratamiento, el uno preconiźa la homeopatía, el otro haće los eloǵios de la dośimetría. ¿Cuálo haćer en semejante circunstancia? Confiar el enfermo a la ciencia del tiempo. Es verdad, el tiempo es un médico habil que obra muy lentamente, pero es un médico muy haḅil y infaliḅle. Por que el enfermo no sufra longo tiempo sería muy bueno de ayudar a este médico por que él haga su obra más presto. Desdichośamente, los hombres que han suponido un diagnóstica justo y que saben que el tiempo es el solo médico que pueda melećinar el mal, son de idea, y nośotros creemos que ellos tienen raźón, que no es posible de prestarle un concurso. Dejemos, dunqüe, al tiempo haćer su hecho y metamos fin a esta consultación que ofrece un espectáculo cómico-tráǵico.

Y para terminar con esta mini antología de textos publicados en 1893 sobre el tema, no podemos dejar en el tintero la magnífica solución que propone, no sé si con su miaja de ironía, quien se firma Han Bušcando en su artículo «El judeoespañol» dirigido a El Tiempo desde Edirne el 29 de diciembre de 1893 y publicado el 4 de enero de 1894 (22/30, 26 tebet 5654, pág. 325a-c). Dice así y algunas de sus palabras parecen proféticas en cuanto a su referencia a los investigadores de la posteridad:

${ }^{32}$ Se refiere al químico y biólogo francés Louis Pasteur (1822-1895).

33 Escrito פיאן, que debe tratarse del químico, físico y matemático francés Anselme Payen (1795-1871). 
Señor el redactor:

En uno de sus últimos números usted tuvo declarado terminada la discusión sobre el judeoespañol. Le demando, dunqüe, mil većes perdón de revenir sobre esta cuestión por las raźones siguientes, de las cuales usted apreciará ciertamente la alta importanza.

Unos ǵenerośos espíritus tomaron parte a esta discusión de un intereso tan palpitante: Esmirna, Salónica, Constantinopla, Sofía, Dresden mismo rompieron lanzas a este sujeto; Andrianopla sólo ni se meneó de su lugar, no diǰo nada, no escribió nada. El historiador que querrá más tarde fixar por la posteridad esta discusión tan importante no faltaría de exclamarse lleno de una justa maravía: «¿Y Andrianopla?..., ¿qué pensaba de esto Andrianopla?; ¿es que por afito esta ciudad se deśinteresaba del judaísmo?». Esta opinión del historiador del avenir sería por nośotros una cruela injuria y que es de nuestro dober de avanzar a nuestros biznietos. ¡Oh, no, esto no puede ser! ¡Esto no será! [...] ¿y nośotros no nos interesaríamos a una cuestión como esta que sulevantan tan eminentes puḅlicistas? Andrianopla, que fonda cada semana una nueva sociedad destinada a espandir chorros de luź y de civiliźación; Andrianopla, onde es menester bušcarlo con candela para topar un hombre, viejo o mancebo, que no haga parte de algún comité de sociedad; Andrianopla ¿restaría, dunqüe, las manos apegadas y la boca cośida delantre una semejante cuestión? ¡Esto es imposible! Es estas graves raźones que justifican la grande liḅertad que yo tomo a escribir a usted.

Yo no estó de su idea, se lo declaro francamente, se' el redactor, cuando él cree que debemos dejar al tiempo el cudio de reglar esta cuestión. No, la solución nos se haće menester inmediatamente. ¡Aḅandonemos esta miśerable lingua!, y una vez que no puedemos pasarnos de una lingua, ¡eh bien!, yo propośo de adoptar el volapuk. [En nota al pie se explica: Volapuk es el nombre de una nueva lingua inventada por un sabio alemán y destinada, según él, a servir en el avenir de una lingua universal por todos los pueblos de la tierra. Esta lingua es muy facil a aprender. Actualmente publican en esta lingua munchos libros y jornales.]

Esta lingua es la que conviene lo mejor a nuestras inteliǵenzas. Y después hay un grandísimo avantaje: esta lingua se envezza en 10 a 15 días, según es sabido de todos. Sería muy práctico de adoptarla y veríamos ansí este único ejemplo en la historia humana de un pueblo trocar su lingua y reǵenerarse en el espacio de 15 días. Hoy su estimada gaćeta aparece en judeoespañol; si mi idea es agradecida ${ }^{34}$, en manco de un meś él puedrá publicarla en... volapuk, con este avantaje de tener aḅonados hasta en el J́apón y la Quina. Yo

${ }^{34}$ Es decir, si es acogida con agrado. 
me cargo en Edirne de echar las baśes de una sociedad con el título «Dorešé lašón... volapuk» ${ }^{35}$.

Adrezar las demandas de adheśiones a Ḥan Bušcando.

\subsection{Opiniones de 1900}

Como no podía ser menos la batalla continuó y unos años después, en 1900, esto es lo que D. Rogman (escrito siempre en letras latinas) propone en La Época 25:1229 (1 adar II 5660 / 2 marzo 1900, págs. 1a-2a), de nuevo en favor del turco e insistiendo en la necesidad de que todas las materias del programa escolar de las escuelas comunales se enseñen en esa lengua:

La lingua turca.- ¿Se puede imaǵinar alguna cośa más bruta, más oriǵinala de una persona dićiéndose apartener a un grande y gloriośo país y non conociendo la prima palabra de la lingua del país al cual él apartiene? ¡Qué sangre de oro cuando en un lugar lonĝe de la cara patría algún funccionario te demanda en tu lingua de ánde vienes y ánde vas, el quedar la boca abierta, la facha esprimiendo la maravilla y tuviendo el aire stúpido de aquel que non entiende la prima palabra de lo que le viene demandado! ¿Con qué cara se puede atorgar que non se conoce su lingua? ¡Triste!... ¡Triste!...

Y, portanto, es esto lo que mos ariba a mośotros, los tres cuartos de iśraelitas morando en Turquía deśde cuatrocientos años. Es mośotros que haćemos esta bruta figura cuando mos hablan en esta lingua que todos debíamos conocer y que apena un chico número conoce. Non basta esta constatación que cierto non es a muestro avantaje; es menester de ajuntar que este estado de cośas va siempre prolongarse si non vienen tomadas las meśuras enérĝicas que las circunstancias comandan por anular el mal una veź por siempre.

Un movimiento se haće de tiempo en tiempo en nuestros jornales en favor de la lingua turca. La Época diversas većes -endimás cuando sobre la iniciativa de nuestro redactor en capo se había fundado el curso turco ande diversos mancebos venían cas̀e cada tadre- habló muy a propóśito haćiendo resalir todos los avantajes si conocíamos esta lingua. En pasadas El Avenir también habló a este sujeto y en uno de sus últimos números el

${ }^{35} \mathrm{Hb} . . .$. דורשי לשון Amantes de la lengua ...'. El volapük se trata de una lengua inventada en 1879 por el sacerdote alemán Johan Martin Schleyer. Al parecer en un primer momento ganó numerosos adeptos, pero las complejidades de su sistema le hicieron perder terreno en beneficio del esperanto. A título de curiosidad cabe decir que en España existió una Sociedad Volapükista Matritense, que en 1886 fundó una revista mensual literaria y científica llamada Volapuk, impresa a dos columnas -castellano y volapükense-, que se imprimía en Guadalajara. 
Se’ A. Eskenazi ${ }^{36}$ haće una llamada a todos los que saben tomar péndola por non dejar la cuestión de la mano y criar el camino que mos puede llevar a un reśultado.

En efeto, como lo diće el sudito señor, es menester que todos los iśraelitas, fieles súditos otomanos, tengamos enclavado en el corazón en una manera que no se embara que muestro más sacro dober, muestro principal interés al punto de vista nacional y particular es de conocer la lingua turca, al meno [sic] como conocemos este jargón judeoespañol del cual nos servimos por darmos a entender.

¿Qué se puede haćer para aribar a este punto?

Hay un remedio mucho sémplicee. Es aquel de adoptar esta lingua -muestra lingua-como lingua principala. Es menester que el niño la sienta deśde la más tierna edad. En corto, es menester de haćer por ella lo miśmo que hićimos para aribar a hablar en esta mezclatina que hablamos. Se quere revolucionado el enseñamiento en todas muestras escolas comunales y particulares. Todo lo que se enseña en todas muestras instituciones: la gramática, la aritmética, la contabilitá, la cencia y el resto debe ser enseñado en turco. Por los más chicos raportos de un elevo a otro, de un elevo a un profesor, de maestro a maestro, en curto, todo, asolutamente todo debe ser hecho en turco; y es sólo estonces que seremos «turcos», como lo somos en efeto y lo debemos de ser, y que embeźaremos muestra lingua de la manera la más naturala.

Hasta que lo todo se va bornar a artículos de jornales, la situación quedará la miśma y continuaremos a dećir que somos turcos sin conocer, ¡helás!, la álef ${ }^{37}$ de esta lingua tan graciośa y armoniośa para el que la conoce y la entiende.

Pero, a pesar de la evidente necesidad de aprender turco que tenían los sefardíes, al parecer no pocos rehusaban hacerlo, quizá llevados por la idea de que eso era salir de Guatemala -el judeoespañol- para ir a Guatepeor -el turco-, que desde luego a muchos no les parecía una lengua especialmente útil para sus contactos con Occidente. Y criticando la postura de estos reacios, esto es lo que se nos dice al respecto en La Época 25:1230 (8 adar II 5660 / 9 marzo 1900, pág. 7a-b), en un artículo firmado por «Véritas» (el seudónimo en letras latinas):

La lingua turca.-El Se’ D. Rogman dećía la semana pasada: «¿Se puede imaǵinar alguna cośa más bruta y más oriǵinala de una persona dićiéndose apartener a un grande y gloriośo país y non conociendo la prima palabra de la lingua del país al cual apartiene?». Y yo ajunto: ¿se puede imaǵinar cośa

\footnotetext{
${ }^{36}$ Escrito en letras latinas.

${ }^{37}$ Escrito con el signo de esa letra en letra cuadrada y de cuerpo mayor.
} 
más inconveniente, más vergüenzośa de algunos mancebos que tuviendo los meźos de embeźar la lingua turca, la repuǰan, la olvidan?

$\mathrm{Y}$, portanto, es verdad. Cuando yo estaba aínda en la escola y tenía una vera pasión por esta lingua, muchos de mis compaños de clasa a los cualos consejaba de embeźarla se burlaban de mí llamándome no sé cuálo y me dećían: «¿Qué menester tenemos mośotros de la lingua turca? Mośotros no tenemos ni la esperanza ni la idea de empiegarmos en alguna administración otomana o de haćermos "quiatipes"; basta que conozcamos como se debe el francés, el italiano, el alemán y la contaḅilitá, y muestro avenir es asegurado, mientres que de la lingua turca no esperamos dingún provecho».

Ma los fatos vinieron a deśmentir sus insinuaciones: muchos de ellos pedrieron hermośos y avantajośos empiegos por no conocer muestra lingua, mientres que algunos otros más claroveentes ${ }^{38}$ que embeźaron este idioma se topan hoy brillantemente plazados. Todavía, mis compaños de clasa pueden ser escuśados un poco, siendo ellos formulaban semejantes ideas ingratas en una época ande tenían poca experienza de la vida y poca concencia de sus actos. Ma no lo pueden ser de miśmo algunos muchachos que, tuviendo parfecta y ex́acta conocencia de sus dober de hombre y de civdadino, mostran un cierto deśdeño y yelor por la lingua de el país; ellos haćen proba de poco patriotiśmo, de poco amor nacional y de ingratitud verso un goberno de tolerencia, liḅertad y hospitalidad.

En Francia, en Italia, en Alemania y todos los otros estados, la prima lingua a enseñarse en las escolas es la lingua del país, y todos los moradores sin distincción de reliĝión son «obligados» de hablar la lingua oficiala, mientres que muestro goberno mos deja llena liḅertad. Por mostrarmos diños de esta liḅertad debemos embeźar el turco sin que seamos obligados.

Si echamos una ojada en las grandes administraciones otomanas, constataremos con desplaćer que el número de empiegados ĵidiós es muy pequeño, mientres hay muchos gregos, armenos, búlgaros y otros. Esta es también una de las cavśas por las cualas numerośos muchachos, bien instruidos ma iñorando el turco, se topan sin hecho.

Pensemos, dunqüe, una buena vez que muestro dober es de mostrarmos fieles servidores del goloriośo Imperio otomano, cultivar las cencias y la literatura turcas, probar que tenemos un corazón y que mos mostramos reconocientes verso todos los que mos acordan sus protección. Cuando conoceremos como se debe la lingua oficiala, muchas cargas y diñidades que no puedemos alcanzar fin hoy mos serán confiadas por endelantre y esta será una buena paga para todos mośotros. La lingua turca non es tanto difícil cuanto la creen muchos; bastan una buena veluntad y un método de enseñamiento moderno por embeźarla a perfección, ande más por mośotros orientales, que embeźamos muchas linguas con la más grande facilidad.

${ }^{38}$ Es decir, otros con más vista, clarividentes. 
Mi opinión sería que quen de derecho se ocupará seriamente de la cuestión, que es de las más delicadas, con el concurso de hombres competentes se puede parvenir a acordar la supremacía a la lingua turca, mientres que las otras sean facultativas en muestras escolas comunales y particulares ${ }^{39}$.

D. Rogman insiste en la «inmersión lingüística» escolar en el siguiente artículo en pro del turco, que apareció asimismo en La Época 25:1234 (7 nisán 5660 / 6 abril 1900, pág. 6a-b), aconsejando aplicar los mismos castigos que reciben los alumnos de la Alianza cuando osan hablar entre ellos en judeoespañol:

La lingua turca.- Sería depasado el pedrerse en raźonamientos por mostrar que todo modo de civdadino debe conocer la lingua del país. Por lo que concerna la lingua turca entre mośotros, iśraelitas otomanos, todos estamos convencidos del dito menester asoluto y de su utilidad indiscutible. Echemos un ojo solamente por ver en qué manera esta lingua -muestra lingua- está enseñada en las escolas comunales y particulares por rendermos cuento de las raźones por las cualas no la conocemos y por bušcar el remedio de aqüistarla y de adelantarmos en ella.

Todo tiempo que muestro mañánimo monarca ${ }^{40}$ mos acorda llena libertad en lo que concerna el tener muestras escolas, muestro primer cuidado debía ser de enjemplarmos a las escolas turcas. Por lo que toca el embeźamiento de la lingua del país -muestra lingua-, debíamos de imitar sus programas, tomar sus métodos, y miśmo debíamos procurar, con la más grande ardor, de igualarlas si no sobrepasarlas. Los ladinos empleados por facilitar el entendimiento del lašón hacodeš, los diversos ex́ercicios por preparar la inteliĝenza y el juźgamiento de los elevos, todos debían de haćersen en turco. El principal dober del corpo enseñante sería de no dejar pronunciar nunca a un elevo un vierbo en otra lingua, y por aribar a esto se debría emplear las puniciones que se emplean ordinariamente en muestras escolas por los elevos que no hablan en francés.

Un elevo que frecuenta mientres tres o cuatro años una escola turca, escluśivamente turca, sale de ahí pudiéndose espiegar muy fácilmente en turco, miśmo si él se aplicó flacamente por lo que concerna el estudio de los cursos en ĝeneral; mientres que un elevo que frecuenta muestras escolas -ande el turco, portanto, viene enseñado mientres diversos años- no sabe atar dos fraśas una a lado de la otra, y el que ariba a quitar la escola con las

39 El mismo autor «Véritas» vuelve a ocuparse del tema en su artículo también titulado La lingua turca, publicado en La Época (29 adar II 5660 / 30 marzo 1900) pág. 4b.

${ }^{40}$ El sultán al que se alude es Abdul Hamid II, quien reinó entre el 31 de agosto de 1876 y el 25 de abril de 1909. 
notas las más briantes no se puede meter en meśa ${ }^{41}$ con aquel elevo saliendo de una escola turca. La raźón es clara. El elevo de la escola turca embeźó a espiegarse en turco, todo lo que le vino embeźado en su escola le vino embeźado en turco; mientres que el elevo de muestras escolas o embeźó a espiegarse en español o sintió siempre hablar en francés. Cuanto a haćer lo miśmo por lo que es la lingua turca -la lingua del país que mos abrió sus brazos cuando otro país mos preseguía, mos desteraba de sus tieras dejándomos deśnudos y crudos ${ }^{42}$, sin piadad por muestros chiquitos ni por muestros viejos-, aínda no se habe empleado la vera manera de estudiarla como estudiamos las otras linguas. Y esto cuando ya mos dio enriba más de cuatrocientos años ${ }^{43}$ que ỵivimos en este país lleno de clemenza, goźando de todas las libertades y de todos los diritos.

No mos contentemos con dećir que hablar a propóśito de la lingua turca en los jornales es haćer la repetición de lo que ya se tiene dicho muchas većes a este sujeto y dećir que a la prósima vez que se va hablar será por aviśar los lectores que se están tomando las dispośiciones por el adelantamiento de muestra lingua, eĉetre, eĉetre. Estas meśuras se queren tomadas presto y enérǵicas. Hasta que se aribe a esto non se quere cansado de gritar. Es un dober caro y sacro para cada civdadino de contribuir a que el turco, la lingua de muestros bienhaćedores, tome el lugar de las otras.

El que va tomar la iniciativa de criar o amejorear lo que ya hay por aribar a que los iśraelitas otomanos hablen el turco, aquel va render a la patría un gloriośo servicio y a los jidiós de Turquía una fuerza que nada no puedrá aflacar.

Como siempre el tiempo fue el sanador de todos los males. Recordemos que a partir del mencionado decreto de Kemal Atatürk en 1928 y con la implantación en Turquía hacia esas mismas fechas de la reforma en la enseñanza, entre cuyas innovaciones figuraba la obligación de estudiar turco en todas las escuelas del país, cambió radicalmente la situación de desconocimiento que de tal lengua tenían las masas sefardíes. Al final el poder estatal intervino y los sefardíes, quieras o no quieras, tuvieron que aprender turco. Las nuevas generaciones de periodistas sefardíes que surgieron tras la reforma estaban desde el punto de vista lingüístico plenamente incorporadas a la lengua del país y fueron introdu-

41 Nehama Dictionnaire s.v. méza recoge la expresión «no se mete en meza» que explica 'il est indigne d'être accueilli dans la bonne société (Se dit de quelqu'un de méprisable)'; es decir, no puede sentarse a la misma mesa, no se puede comparar.

42 Nehama Dictionnaire s.v. krúdo explica la locución «salir krudo y desnudo» como perder toda su fortuna, quedarse sin un céntimo.

43 Es decir, cuando ya han pasado más de cuatrocientos años; vid. en NeHAma Dictionnaire s.v. dar (pág. 115) la expresión dar enriva. 
ciendo el turco en la prensa, siendo al mismo tiempo esta lengua también cada vez más reclamada por los propios lectores.

Así pues, en la ya Turquía moderna desde antes de mediado el siglo XX el turco fue ganando en la prensa sefardí espacio al judeoespañol, acelerándose el proceso después de la Segunda guerra mundial y quedando el judeoespañol relegado a tan sólo alguna página o columna para finalmente desaparecer.

\section{UNA SABIA APRECIACIÓN EXTERNA}

Por lo que tiene de curioso e interesante quiero acabar este artículo con las palabras de quien no necesita presentaciones para los especialistas y que se firma (en letras latinas) «Commandant Lamouche». Esta colaboración, que apareció en El Avenir de Salónica 9:25 (19 siván 5666 / 12 junio 1906, págs. 6a-7a), puede servir como broche y a modo de resumen de todo lo expuesto hasta aquí. Así se presenta el artículo:

Un oficier francés sobre nuestro judeoespañol.- El comandante Lamučh, oficier francés del servicio de la jandarmería, se interesa con pasión al estudio comparativo de las linguas evropeas y orientalas que él conoce parfetamente. Él es un buen amigo de nuestro pueblo y viene de ajuntar sus oḅservaciones sobre el judeoespañol comparado al puro español castillano por ser publicadas en un recolio científico. Él tuvo la gentileźa de otoriźarmos a treśladar de su manuscrito la introducción sigüente, por lo cualo le adrezamos nuestros sinceros regraciamientos.

Recordemos que efectivamente Leon Lamouche estaba por entonces en Salónica formando parte de la comisión internacional creada para reorganizar la policía turca (la jandarmería mencionada) ${ }^{44}$ y lo que a continuación sigue es el texto traducido de las primeras cuatro páginas del artículo de Lamouche «Quelques mots sur le dialecte espagnol parlé par les Israélites de Salonique» que el filólogo comandante publicó un año después (1907) en la revista Romanische Forschungen 23 (págs. 969-991). He aquí el texto en versión judeoespañola:

Ya saben que el más grande número de los yisraelitas que moran actualmente en el Imperio otomano decienden de los jidiós españoles y portugueśes desterados de España y Portugal en los últimos años del $15^{\circ}$

44 Vid., por ejemplo, Lillian Petroff, Sojourners and Settlers: The Macedonian Community in Toronto to 1940 (Toronto 1995) pág. 158. Recordemos que a finales del siglo XIX y a causa del permanente estado de alteración en Macedonia, foco de reformistas, de un lado, y de bandoleros, de otro, las potencias europeas impusieron al sultán un régimen especial de policía mandada por oficiales europeos; vid. al respecto RoMERo Entre dos cap. 7 págs. 296-297. 
sieclo y el empecijo del $16^{\circ}$. Ellos fueron recibidos con apreseramiento ${ }^{45}$ de parte de las otoritás otomanas y se estabilieron en las principalas civdades de la Turquía de Evropa y de Anatolía. Estos yisraelitas, llamados sefaradim, quere dećir 'españoles', se encontran en todas las civdades importantes del Imperio turco, en Bulgaría, en Serḅía y miśmo al sud (darom) de la Rumanía (por enǰemplo, en Bucarest).

La civdad que se puede considerar como el centro de la populación judía de Oriente es Salonico, ande los yisraelitas forman ciertamente la maýoritá de los moradores, más de la mitad dićen los unos, los dos terzos pretenden los otros.

Toda esta populación judeo-orientala quedó fiela a la lingua que hablaban sus agüelos del $15^{\circ}$ siécolo. Esta fieldad le fue del resto facilitada por la grande tolerencia del goberno otomano en hechos semejante [sic]; cale reconocerlo a sus alabación, los turcos dejaron siempre toda liḅertad a sus súditos no muśulmanos en lo que concerna la conservación y el deśvelopamiento de sus linguas y de sus tradiciones nacionalas.

Las relaciones políticas y comercialas entre la España y la Turquía, siendo deśde longo tiempo muy poco importantes, los emigrados se toparon complidamente apartados de sus vieja patría y sus lingua dubo tomar un deśvelopamiento independiente. Ansí, ella no puedía mancar de coromperse. Al tiempo de la emigración ella ya contaba una cierta cuantidad de yierbos 'heḅraicos raportándosen principalmente, cuantunque no solamente, a las cośas reliĝiośas y moralas. Después del estaḅilimento en Oriente, una grande cuantidad de vierbos y de fraśas turcas fueron entrados en el judeoespañol como en todas las otras linguas de la península de los Balcanes. El italiano, que fue mucho tiempo de un empleo general en los portos de Oriente, ex́erzó él también una influenza bastante notable sobre el judeoespañol, particularmente en las civdades marítimas. En fin el francés, que es actualmente la lingua evropea la más espandida en las grandes civdades de Turquía y que es también la lingua del enseñamiento en las escolas, numerośas y bien organiźadas, de la Alianza Yisraelita Universala, haće sentir él también su influenza sobre la lingua y la compośición del judeoespañol. Actualmente los escribanos que se sierven de esta lingua tienen la tendencia de meter lo más posible yierbos tomados del francés o del italiano o nuevos términos formados sobre el modelo de estas linguas, en lugar de los yierbos turcos o 'heḅraicos, miśmo en las publicaciones de carácter popular.

Las otras linguas indíǵenas, aparte del turco, ex́erzaron sobre el judeoespañol una influenza mucho manco considerable $[\ldots]^{46}$.

${ }^{45}$ La palabra traduce fr. empressement (pág. 969).

46 En el original aljamiado se marca con una serie de puntos la supresión de un pasaje del texto de Lamouche (pág. 970). 
El judeoespañol no es un linguaje no cultivado, como lo puedría haćer creer el término «el jargón» (vierbo francés, el término castillano es «la jerga») por el cual los yisraelitas ellos miśmos deśiñan a coruto ${ }^{47}$ sus lingua madre. El judeoespañol es la lingua sociala de las comunitás yisraelitas; ella es empleada en la vida reliĝiośa y económica. En la sinagoga como en el magaćén del comerzante, el judeoespañol fue siempre una lingua cultivada. Él tiene una literatura compuesta en primer lugar de libros tratando de reliĝión y de moral, con los cualos contrastan agora las traducciones de romanzos franceśes. Del resto, la instrucción fue siempre un honor en las comunitás ${ }^{48}$ judías de Oriente.

Actualmente la tendencia de las clasas aclaradas verso los uśos evropeos, la introducción de un enseñamiento sólo francés en las escolas yisraelitas las más frecuentadas, ayudan ciertamente a haćer descayer el judeoespañol de la situación que él ocupó mientres cuatro siécolos. Ciertos yisraelitas se demandaron miśmo si no sería preferable por sus nacionalitá de aḅandonar la lingua de sus agüelos y de adoptar una otra como lingua nacionala. Pensaron también, ma en España más presto que en Oriente ${ }^{49}$, a atar de nuevo los ataderos hoy enteramente rompidos entre los hijos de los desterados del 1492 y la vieja patría madre, de continuar por consegüenza la unificación del judeoespañol con el castillano.

Estos proýetos tienen pocas čhances de realiźarsen. Nada no permete de preveer un acercamiento intelectual con la España, donde el nombre no desperta ningún sentimiento ni ningún suvenir preĉiśo en el esprito de los yisraelitas de Oriente ${ }^{50}$. Muy pocos jidiós, miśmo instruidos, meldan libros o publicaciones españolas. Si uno de ellos quere escribir su lingua con caracteres latinos, él se servirá de las reglas de escribir franceśas y no de las reglas españolas que le son desconocidas. Del resto, las relaciones comercialas son cas̀e nulas y no hay colonías españolas en los grandes portos de Turquía.

La conocencia y el empleo de las linguas evropeos [sic], particularmente del francés, yirán ciertamente deśvelopándosen, ma la lingua tradicionala continuará a ser conservada.

Malgrado la favor acordada a las otras linguas, el judeoespañol tiene siempre una fuerza de vida que no se puede niegar. Él es siempre la lingua oficiala de las comunitás yisraelitas por todos los hechos reliĝiośos. Afuera

${ }^{47}$ Con este turquismo se traduce fr. souvent (pág. 971).

48 Así se traduce fr. «L'instruction a, du reste, toujours été en honneur dans les communautés juives du Levant» (pág. 971).

49 Así se traduce el fr. «mais en Espagne plutôt qu'en Orient» (pág. 971). Lamouche alude a los flacos intentos hechos desde España y derivados de la campaña de Pulido.

50 Ya hemos visto cómo de despertar algún sentimiento éste era más bien de hostilidad. 
de algunas caśas muy importantes que se sierven del francés o del italiano, los mercaderes yisraelitas tienen sus contabilitá y haćen sus corespondencia en judeoespañol. Sobre todos los magaćenes se ve aviśos y inscripciones en caracteres 'hebraicos. Cuando la administración municipala quere traer algún orden a la conocencia del público por vía de aviśos apegados en las paredes (lo que, a la verdad, es bastante raro), al lado de la copia turca y grega figura una traducción en judeoespañol. En fin, la prensa judeoespañola tiene sus órganos en todas las grandes civdades de la Turquía y de los países većinos. Dos jornales en judeoespañol, La Época y El Avenir, aparecen en Salónico; dos igualmente, El Tiempo y El Telégrafo, en Constantinople; hay también de ellos en Esmirne, en Eĝito, en Bulgaría.

Se puede, dunqüe, preveer que esta rama iśolada del tronco romano yivirá aínda longo tiempo en conservando su aspecto actual o en modificándose avagarośamente con la introducción de vierbos nuevos. Quién sabe miśmo si el avenir no destina a una importanza más grande este linguaje de un pueblo esencialmente inteliĝente, laboriośo y paćiguośo.

Lamouche contemplaba el judeoespañol desde fuera y con la frialdad de un estudioso bien lejana del apasionamiento de sus hablantes, que incluso, como hace David Fresco, le niegan la evidencia de lengua de cultura. Sus argumentos resultan en muchos aspectos proféticos: descalifica a los que consideran el judeoespañol como una jerga, pone el dedo en la llaga sobre la entrega sin resistencia al francés de las «clasas aclaradas», ve imposible el acercamiento al castellano, y afirma que «la lingua tradicionala continuará a ser conservada».

\section{Conclusión}

¿Y cómo se ha conservado?: pues malamente ${ }^{51}$. Hemos leído un conjunto de textos de finales del siglo XIX y principios del XX en un judeoespañol vigoroso y cargado de expresividad usado, paradójicamente, para decir que esa lengua era una jerga abominable de la que había que desprenderse. ¡Ya quisiéramos que los periodistas sefardíes de ahora fueran capaces de expresarse como aquellos sus predecesores! Lo cierto es que con tales opiniones de partida no cabía esperar mucho del futuro, y ciertamente de aquellos polvos -en el literal sentido de la palabra- del desprecio de los sefardíes por su lengua vernácula vinieron estos lodos. Finalmente sí tuvo razón David Fresco, ya que efectivamente fue el tiempo -el real y no su periódico- con ayuda de los acontecimientos históricos

${ }^{51}$ Sobre la situación de la lengua en la actualidad pueden verse los interesantes comentarios de Isaac Papo en su artículo «El judeoespañol hoy: Consideraciones de un usuario», Raíces 52-53 (2002) págs. 31-36. 
el que puso las cosas en su sitio y se encargó de solucionar la cuestión de la pervivencia del judeoespañol.

Hagamos un resumen de lo dicho. En el transcurso del siglo XX se va produciendo el ya imparable declive de la lengua judeoespañola que lleva anejo la inevitable minusvalía actual de su literatura.

Las aludidas nuevas nociones culturales surgidas a finales del siglo XIX y las nuevas realidades histórico-sociales que se fueron sucediendo a lo largo del siglo XX dieron el golpe de gracia a la cultura específicamente sefardí. Ya hemos visto cómo primero los intelectuales sefardíes se arrojaron en brazos de la lengua y de la cultura francesa como imperativo para entrar en la modernidad. El desprecio de aquellos intelectuales por la lengua que les había servido durante siglos como vehículo de comunicación y como instrumento de creación literaria influyó sin duda en el resto de la comunidad sefardófona.

Más tarde todo el grupo social, encabezado por los jóvenes y respaldados éstos de grado o por fuerza por los mayores, fue subiéndose paulatinamente al carro de las lenguas ambientes impulsados todos por la necesidad vital de integrarse en el mundo cultural y lingüístico de los países de residencia. Tal proceso de integración fue además auspiciado o impuesto desde los nacionalismos gubernamentales e ideológicos.

Y así fue quedando relegado al consumo familiar y al nivel coloquial la lengua tradicional -el judeoespañol-, tenido por «jargón bastadreado», impura prolongación del castellano y que además y por si lo primero fuera poco, había sido la lengua de los inquisidores y de los pérfidos reyes que acabaron con el judaísmo hispánico.

Todo ello fue seguido por el desarraigo de su tradición castiza, por el desinterés total hacia sus clásicos, es decir, hacia cuanto se había producido en lengua sefardí en los siglos anteriores y que, escrito en caracteres rašíes, ya no eran capaces de entender.

En cuanto al olvido de sus clásicos hay que recordar que casi toda aquella riquísima producción literaria anterior hay que encuadrarla en el marco de lo que he denominado literatura patrimonial, es decir, la que se inserta en el continuum de la llamada hojmat Yisrael o sabiduría del pueblo de Israel, en suma, la literatura de corte y contenidos rabínicos que ya para estas fechas interesaba a muy pocos y desde luego entre esos pocos no se contaba la gran mayoría de los jóvenes intelectuales a la moderna volcados a lo que he denominado literatura de adopción ${ }^{52}$.

52 Sobre tales denominaciones vid. mi libro Creación págs. 22-23 y mi artículo «Historia y literatura» págs. 167-168. 
En cuanto a los caracteres rašíes, ya hemos hablado supra del paulatino abandono de los mismos a partir de 1928.

Con el olvido de todo aquello, inconscientemente acabaron equiparándose a sí mismos, como lo hacía David Fresco, a aquellos pueblos que carecen de toda tradición literaria.

En las décadas de transición del siglo XIX al XX tuvo además lugar una fuerte corriente de migración hacia los países más adelantados de Europa y América, a las colonias europeas en África, a la Palestina del mandato británico en Asia, e incluso a Oceanía. En las nuevas circunstancias que propiciaban los nuevos entornos geográficos y socio-culturales el proceso de desarraigo de la cultura propia ha seguido su imparable curso, quedando el judeoespañol ahogado por las lenguas de los nuevos países de asentamiento. Esas nuevas comunidades sefardíes fruto de las corrientes migratorias señaladas y de otras posteriores, son sefardíes desde el punto de vista genealógico, pero prácticamente ninguna lo es desde el punto de vista cultural.

El mundo sefardí -especialmente el de Grecia y el de la antigua Yugoslaviaaún habrían de sufrir un nuevo y literalmente mortal golpe con la deportación y el exterminio sufrido durante la última guerra mundial a manos de la barbarie nazi.

Tras la guerra se acentuó la emigración de sefardíes a Israel, donde también, sobre todo en las primeras décadas del entonces joven estado, fue intensa la tendencia a fundir en el crisol de una cultura israelí común a todos los hijos de los inmigrantes llegados de los más variados países.

Y aún más: para aumentar en lo posible la brecha con su origen, en las últimas décadas se viene afirmando en Israel que el judeoespañol es una «lengua judía» que nada tiene que ver con el español y para su representación escrita se busca con candil y con ahínco una forma gráfica lo más alejada posible de la hispánica, no sea que alguien se vaya a llevar a engaño. ¿Y con ello qué se ha conseguido?: pues salir del gueto que significaba el uso de la grafía hebrea para entrar en otro -el de la grafía latina antihispánica- que impide que la literatura sefardí actual -por escasa que sea- haya tenido la difusión y la acogida que hubiera podido tener de parte de los muchos millones de hablantes y de lectores de español esparcidos por el ancho mundo, a quienes la aberración gráfica les impide entrar en el texto literario.

Así pues, de alguna manera, aquellos que discutían sobre su lengua y proponían su erradicación lograron lo que se proponían: la muerte del judeoespañol. En la actualidad la muy empobrecida lengua, bien lejana de su riqueza anterior y de su antigua capacidad expresiva, en términos generales ya no puede ser considerada como una lengua literariamente creativa. 
Y ante tal situación, yo, que gusto de la producción literaria judeoespañola de los siglos pasados y que disfruto con sus creaciones y con sus innovaciones léxicas, sólo puedo decir con todo el dolor de mi corazón: Baruj dayán haemet.

\section{GLOSARIO $^{53}$}

acavidamiento 'consejo prudente, advertencia'.- aclarada 'iluminada'; las clasas aclaradas 'los intelectuales' .- acordar (fr. accorder) 'conceder'.--adrezar (fr. adresser) 'dirigir'.- aerada (fr. aéreé) 'aireada'.- afito: por — 'por casualidad'.- 'a'h (hb. עליהם השלום 'abrev. de hb. עליהם 'alehem hašalom, lit. 'sobre ellos sea la paz') 'que en paz descansen'.- aiśolamiento (fr. isolement) 'aíslamiento'; vid. tb. iśolar.- aĵuntar (it. aggiuntàre, fr. ajouter) 'añadir' .- álef (אל) 'a', primera letra del alefato.- alora (it. allora) 'ahora'.- apartener (fr. appartenir) 'pertenecer' -- apreseramiento: vid. nota 45.- aqüistar (cfr. fr. acquis, part. pas. de acquérir) 'adquirir, ganar'.-- aškenaźim (hb. אשכנזים) 'asquenasíes' .- atorgar 'reconocer, otorgar'.- avagarośamente (cfr. esp. vagaroso) 'lentamente'.- avanzar (it. avanzáre) 'evitar, ahorrar'.- 'avonot: vid. kaparat.- bornarse (fr. se borner) 'limitarse'.- bruta (it. brútta) 'fea' - - caler 'ser necesario, tener que, haber de'.- carear 'acarrear, provocar'.- čhances (fr. sing. chance) 'probabilidades'.- civdadino (cfr. it. cittadino) 'ciudadano' .- claroveentes: vid. nota 38.- Cohélet ( $\mathrm{hb}$. קהלת) 'Eclesiatés' .- colonas (fr. sing. colonne) 'columnas' .- contradas (it. sing. contrada) 'tierras, regiones' .- coruto (cfr.

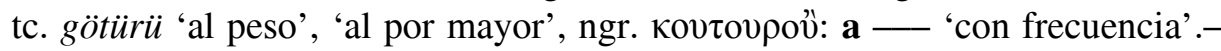
criado 'criatura, ser humano'.- cuantunque (it. quantunque) 'aunque'.- Cušta 'Constantinopla'.- daitš: vid. yidišs.- darom (hb. דרום) 'sur'.- deśvelopamiento (fr. développement) 'desarrollo'.-- din (hb. דין) 'norma'.- diritos (it. sing. diritto) 'derechos' -- dober (cfr. it. dovere) 'deber'.- dubio (it. dubbio) 'duda' - - dunqüe (it. dunque) 'así pues'.- eceetre (cfr. it. eccetera)'etcétera'.- eguardo (cfr. fr. égard): por — 'por consideración, por respeto'.- elevo (fr. élève) 'alumno'.embarar (cfr. fr. barrer) 'borrar, tachar'.- embeźar: vid. enveźar.- empecijo 'principio'.- empiegados (it. sing. impiegato) 'empleados' .- empiegar (it. impiegare) 'emplear, usar'; empiegarse (it. impiegarsi) 'colocarse, emplearse'.empiegos (it. sing. impiego) 'empleos'.-- entípedas 'antípodas'.- entrefleto (cfr. fr. entre-filet) 'suelto de un periódico'.- entretenida (cfr. fr. entretenue; DRAE s.v. entretener) 'cuidada'.- enỵeźar, embeźar 'aprender, avezarse'.- enṿidia (fr. envie) 'deseo, gana'.- escopo (it. scòpo) 'intención, objetivo'.- espiegar

${ }^{53}$ Me limito a recoger en el Glosario los vocablos que, con criterios subjetivos, pienso que pueden ofrecer alguna dificultad de comprensión al lector hispano culto. 
(it. spiegare) 'explicar'.- esprimiendo (cfr. fr. exprimer) 'expresando, manifestando'.- estabilirse (it. stabilirse) 'establecerse'.- facha (it. faccia) 'cara, rostro'.- facil (fr. facile) 'fácil' .- fatos (it. sing. fatto) 'hechos'.- fieros (fr. sing. fier) 'orgullosos'.- figura (fr. figure, esp. figura) 'cara, rostro'.- fin (tb. it. fino) 'hasta' - - fondar (fr. fonder) 'fundar' -- guebir ha'elión: vid. hag̉uebir.- Guemará (hb.-arm. גמרא): comentario arameo a la Mišná, que junto con ésta constituye el Talmud.- H' (hb. 'ה, abrev. de השם lit. 'el Nombre', se lee Adonay) 'Dios' .- habe 'ha'.- haḅil (fr. habile) 'hábil' .- hacodeš: vid. lašón.- hadašot (hb. חדשות) 'novedades, noticias'.- ha'elión: vid. hagiuebir.- haġuebir: (ha) guebir ha'elión: vid. nota 27; — hameromam (hb. - המרומם, -) 'el eximio notable'.- hameromam: vid. haguebir.- hạan (escrito חאן, abrev. de hb. כמרן hajam 'sabio') 'don; tío'.- Hanuká (hb. חנוכה): festividad menor en que se conmemora la purificación del Templo tras la victoria de los macabeos sobre los griegos seléucidas en el año 165 a.e.c.; se inicia el 25 del mes de kislev-que empieza entre el 5 de noviembre y el 3 de diciembre- y dura ocho días.- hecho 'trabajo', 'asunto'.- ¿helás! (fr. hélas) ¡ay!.- hy"v (hb. הי" siglas de hb. haŠem yišmerehu viḥayehu) 'Dios le guarde y le dé vida'.inutil (fr. inutile) 'inútil'.- iśolar (fr. isoler) 'aislar'; vid. tb. aiśolamiento.jandarmería (fr. gendarmerie) 'policía' - - kaparat 'avonot: vid. nota 30.- kefí

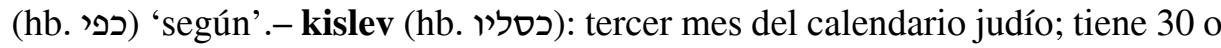
29 días y su comienzo oscila entre el 5 de noviembre y el 3 de diciembre.- ladinos: aquí, 'palabras utilizadas para traducir del hebreo'.- lašón hacodeš (hb. לשון הקודש lešón hacodeš) 'lengua santa', es decir, 'hebreo'.- l'eqüinoccios: vid. nota 26 .- letra (fr. lettre) tb. 'carta'.- ma (it. ma, tc. ama) 'pero'.- magaćén (fr. magasin) 'tienda, almacén'.- malgrado ((it. malgrádo, fr. malgré) 'a pesar de'.- manco (it. manco) 'menos'.- mar (hb. מר) 'señor, don'.- meldadores 'lectores'.- meldar 'leer'.- meśuras (fr. sing. mesure, it. sing. misura) 'medidas'; a meśura 'a medida'.- meterse en meśa: vid. nota 41.- meźos (it. sing. mezzo) 'medios'.- miśmo (fr. même) 'incluso'.- neglijar (fr. négliger) 'olvidar'.- nulamente (fr. nullement) 'de ningún modo, de ninguna manera, en absoluto'.- pale (ngr. $\pi \alpha \dot{\lambda} \lambda \varepsilon$ pali) 'de nuevo'.- paroxitón (fr. paroxyton) 'que se acentúa en la penúltima sílaba, grave'.- parvenir (fr. parvenir) 'llegar'.- pasuc (hb. פסוק) 'versículo bíblico'.- peró (it. però) 'sin embargo, si no'.- plazados (fr. sing. placé) 'colocados'.- portanto (fr. pourtant) 'sin embargo'.- premir (it. premere) 'urgir, apremiar'.- pretender: vid. nota 16 .- preveente (cfr. fr. prévoyante) 'previsor, precavido'.- profitable (fr. profitable) 'aprovechable'.profitar (fr. profiter, it. profittare) 'aprovechar'.- profito (it. profitto) 'provecho'.- proparoxitón (fr. proparoxyton) 'proparoxítono, que se acentúa en la antepenúltima sílaba, esdrújulo'.- puniciones (fr. sing. punition) 'castigos'.- 
querer + part. 'hay + inf.'.- quehilot (hb. קהילות) 'sinagogas'.- quiatipes (tc. sing. kâtib, kâtip) 'escriba, secretario, funcionario público'.- Quina (it. China) 'China'.- quitado (fr. quitté) 'sacado'.- quitar (fr. quitter) 'dejar, abandonar'.raportarse (fr. se rapporter, it. rapportarsi) 'estar en relación con, referirse a'.- raporto (fr. rapport, it. rappòrto) 'relación' .- recolio (it. raccòglio, fr. recueil) 'colectánea' - - recoltar (cfr. fr. récolter) 'recoger, recolectar'.- regraciamientos (it. sing. ringraziamento) 'agradecimientos'.- render (tb. fr. rendre) 'convertir, volver una cosa en otra'; —_ servicio(s) 'prestar un servicio, ayudar, contribuir al logro de una cosa'; renderse cuento: 'darse cuenta'.- resto: del __ (fr. du reste) ‘además, por otra parte, por lo demás'.- revernir (esp. revenir) 'volver'.- romanzos (cfr. it. sing. romanzo) 'novelas'.- safañones 'sabañones'.- safec (hb. ספק) 'duda'.- salutario (fr. salutaire) 'saludable'.- sanglutos (fr. sing. sanglot) 'sollozos, suspiros'.- sea-dicho (cfr. fr. soi-disant) 'pretendido'.--sefaradim (hb. ספרדים) 'sefardíes'.- sémplice (it. sémplice) 'fácil, sencillo, simple'.- servimiento 'servicio'.- solitreo 'grafía aljamiada manuscrita'.soto (it. sotto) 'bajo'.- sudito (fr. susdit) 'sobredicho'.- sujeto (fr. sujet) 'tema, materia, asunto'.- sulevantar (cfr. fr. soulever) 'suscitar, promover'.- suplear (fr. suppléer) 'suplir'.- tirar (fr. tirer) 'sacar, obtener'.- todavía (it. tuttavia) 'sin embargo'.- Torá (hb. תורה) 'la Ley judía'.- t"T (hb. ת"ת, abrev. de hb. תלמוד תורה talmud Torá): nombre que recibían las escuelas comunales, que se dedicaban fundamentalmente a la enseñanza religiosa.- turquinos (cfr. it. sing. turquino) '(judíos) de origen turco'.- vejayos"'é (hb. וכיוצ"א) 'y otras cosas semejantes'.- vejú' (hb.-arm. וכוליה vejulé) 'etcétera'.- vera (it. vera) 'verdadera'.- verso (it. vèrso) 'hacia'.- vierbo 'palabra'.- y'E"'a (hb. יע" יכוננה עליון אמן yejonenah 'Elión amén) 'el Alto la cimente, amén', eulogia habitual tras los nombres de ciudades.- yidiš daitš (al. Jiddisch Deutsch): vid. yudesco.- Yirmiyahu (hb. ירמיהו) 'Jeremías'.- Yisrael (hb. ישראל (Israel'.- yudesco, yidiš daitš 'yídico', lengua de los judíos de origen asquenasí.

Recibido: 15/07/2009

Aceptado: 02/01/2010 